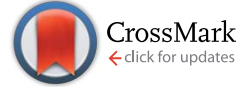

Cite this: RSC Adv., 2017, 7, 5282

Received 2nd November 2016 Accepted 23rd December 2016

DOI: $10.1039 / c 6 r a 26199 j$

www.rsc.org/advances

\section{Synthesis, structural analysis, solution equilibria and biological activity of rhodium(III) complexes with a quinquedentate polyaminopolycarboxylate $\uparrow$}

\author{
Marija S. Jeremić, ${ }^{a}$ Hubert Wadepohl, ${ }^{b}$ Vesna V. Kojić, ${ }^{c}$ Dimitar S. Jakimov, ${ }^{c}$ \\ Ratomir Jelić, ${ }^{d}$ Suzana Popović, ${ }^{d}$ Zoran D. Matovićca and Peter Comba*b
}

\begin{abstract}
Two rhodium(III) complexes $\left[\mathrm{Rh}(\mathrm{ed3a})\left(\mathrm{OH}_{2}\right)\right] \cdot \mathrm{H}_{2} \mathrm{O}$ (1) and $\mathrm{Na}[\mathrm{Rh}(\mathrm{ed} 3 \mathrm{a}) \mathrm{Cl}] \cdot \mathrm{H}_{2} \mathrm{O}$ (2) with ethylenediamine$N, N, N^{\prime}$-triacetate (ed3a) have been synthesized and characterized by elemental, spectroscopic and structural analyses. The crystal structure of (1) and (2) and the spectroscopic analysis of the two rhodium(III)-ed3a complexes are discussed in detail. The protonation constants of $\mathrm{H}_{3} \mathrm{ed} 3 \mathrm{a}$ and the conditional stability constants of its $\mathrm{Rh}^{\text {III }}$ complexes have been determined in aqueous solution by $\mathrm{pH}$ potentiometry and UV-Vis spectrophotometry. Molecular mechanics (MM) and density functional theory (DFT) have been used to model all possible geometric isomers, determine the global energy minimum and compare the computed with the experimentally observed structures. The cytotoxic activity of the new $\mathrm{Rh}^{\text {III }}$ complexes was evaluated by an MTT assay against four human cancer lines (MCF-7, A549, HT-29 and HeLa) and a normal human cell line (MRC-5). A549, HT-29 and HeLa cells were sensitive to all compounds tested, while the breast carcinoma cell line MCF-7 was only sensitive to the reference compounds (doxorubicin and cisplatin). Western blot (WB) analysis of the effects of the tested compounds indicates that both complexes increase the expression of caspase 3 and consequently the involvement of this enzyme in apoptotic processes of the treated cells. WB also demonstrates proteolytic cleavage of poly-(ADP-ribose) polymerase (PARP) in HeLa cells after treatment with both tested substances. Flow cytometry confirmed apoptotic cell death and showed the induction of cell cycle termination as a possible promoter of apoptosis.
\end{abstract}

\section{Introduction}

For a multitude of reasons, transition metal complexes with edta-type aminopolycarboxylate ligands have attracted considerable attention and have been extensively investigated and reviewed., ${ }^{1,2}$ The best studied quinquedentate ligand system is ethylenediamine- $N, N, N^{\prime}$-triacetate (ed3a) and its derivatives. For octahedral metal complexes with pentadentate coordinated symmetrical edta- (ethylenediamine- $N, N, N^{\prime}, N^{\prime}$-tetraacetate) or ed3a-type ligands three possible geometric isomers, cis-equatorial, trans-equatorial and cis-polar are possible

\footnotetext{
${ }^{a}$ University of Kragujevac, Faculty of Science, Department of Chemistry, R. Domanovica 12, 34000 Kragujevac, Serbia. E-mail: zmatovic@kg.ac.rs

${ }^{b}$ Universität Heidelberg, Anorganisch-Chemisches Institut and Interdisciplinary Center for Scientific Computing (IWR), Im Neuenheimer Feld 270, D-69120, Heidelberg, Germany.E-mail: Peter.Comba@aci.uni-heidelberg.de

'Oncology Institute of Vojvodina, Faculty of Medicine, University of Novi Sad, Dr Goldmana 4, 21204 Sremska Kamenica, Serbia

${ }^{d}$ University of Kragujevac, Faculty of Medical Sciences, S. Markovića 69, 34000 Kragujevac, Serbia

$\dagger$ Electronic supplementary information (ESI) available: Further solution study details, IR, ${ }^{1} \mathrm{H}$ NMR, ${ }^{13} \mathrm{C}$ NMR data. CCDC 1412103 and 1412104 for the new compounds are included. For ESI and crystallographic data in CIF or other electronic format see DOI: 10.1039/c6ra26199j
}

(Fig. 1). Most of the reported [M(ed3a-type)X] complexes $(\mathrm{M}=$ $\mathrm{Co}^{\mathrm{III}}, \mathrm{Cr}^{\mathrm{III}}, \mathrm{Cu}^{\mathrm{II}}, \mathrm{Ni}^{\mathrm{II}}$ and $\mathrm{X}=$ monodentate ligand) have the cisequatorial configuration..$^{3-5}$

The success of cisplatin as antitumor agent has stimulated enormous efforts to designing and preparing other clinically useful metal complexes. ${ }^{6-10} \mathrm{Rh}^{\mathrm{III}}$ coordination compounds are isoelectronic with $\mathrm{Ru}^{\mathrm{II}}$ and $\mathrm{Pt}^{\mathrm{IV}}$ complexes, which provide a range of active antitumor agents. ${ }^{\mathbf{1 1}, \mathbf{1 2}}$ Generally, they are octahedral and inert but many $\mathrm{Rh}^{\mathrm{III}}$ complexes show considerable antitumor and antimicrobial activities. ${ }^{\mathbf{1 1 2}}$ The first report of an antitumor active $\mathrm{Rh}^{\mathrm{III}}$ complex, $\mathrm{RhCl}_{3} \cdot 3 \mathrm{H}_{2} \mathrm{O},{ }^{13}$ appeared before Rosenberg's discovery of cisplatin. ${ }^{6,7}$ Simple complexes

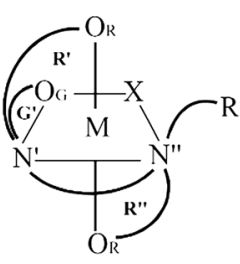

cis-equatorial

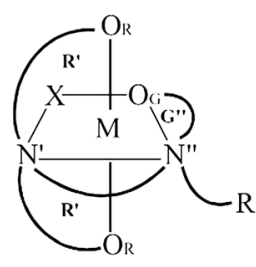

trans-equatorial

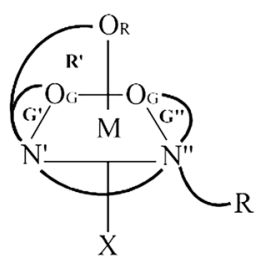

cis-polar
Fig. 1 Geometrical isomerism of six-coordinate [M(ed3a-type)Xn] complexes: $n=1$. 
such as mer- $\left[\mathrm{RhCl}_{3}\left(\mathrm{NH}_{3}\right)_{3}\right]$ or $m e r$, cis-[ $\left[\mathrm{RhCl}_{3}(\mathrm{DMSO})_{2}\left(\mathrm{NH}_{3}\right)\right]$ are also known to be anticancer active. ${ }^{14,15}$ Early work up to 2002 on rhodium anticancer complexes in the oxidation states +1 to +3 was summarized in two review articles. ${ }^{16,17} \mathrm{~A}$ large number of complexes of rhodium has been explored for antitumor activity. ${ }^{18}$ Numerous half-sandwich complexes of Rh such as $\left[\left(\eta^{5}-\mathrm{C}_{5} \mathrm{Me}_{5}\right) \mathrm{Rh}(\mathrm{LL}) \mathrm{Cl}\right]$, where (LL) is a bidentate polypyridyl ligand were prepared and studied in terms of their antiproliferative properties in human cancer cell lines. ${ }^{19-22}$ Rhodium(III) complexes appeared to be a good inhibitors of the kinase, inhibitors of other enzymes and inhibitors of proteinprotein interactions. ${ }^{22}$ Data on the antimalignant activity of rhodium(III) chelated by EDTA-type ligands is very scarce.

Here, we report on the synthesis and coordination chemistry of $\mathrm{Rh}^{\mathrm{III}}$ complexes of $\mathrm{H}_{3}$ ed3a and their medicinal/biological properties. The characterization is mainly based on the octahedral complexes [Rh(ed3a) $\left.\left(\mathrm{OH}_{2}\right)\right] \cdot \mathrm{H}_{2} \mathrm{O}(\mathbf{1})$ and $\mathrm{Na}[\mathrm{Rh}(\mathrm{ed} 3 \mathrm{a}) \mathrm{Cl}]$. $\mathrm{H}_{2} \mathrm{O}$ (2). These contain fully deprotonated quinquedentate ligands, which may form four five-membered chelate rings. The IR, NMR and electronic spectra of these complexes are discussed in relation to their geometry, and the formation constants are used to estimate the in vivo stabilities of the rhodium(III) complexes. Also reported are the results of the two complexes' cytotoxicity in vitro towards diverse tumour cell lines and first results on the mechanisms of antiproliferative activity of the new $\mathrm{Rh}^{\mathrm{III}}$ complexes against human cervix adenocarcinoma cells. The effects on expression of proteins included in apoptotic signalling pathways (Bcl-2, Bax, caspase-3, and poly(ADP-ribose) polymerase, PARP) as well as cell cycle phase distribution of HeLa cells were monitored. A WB analysis was used to evaluate the expression levels of apoptosis-associated proteins.

\section{Results and discussion}

\section{Coordination chemistry}

Chelates of ed3a-type ligands can be prepared: (a) by the condensation method, starting from a neutralized $\alpha$ - or $\beta$ monohalogencarboxylic acid and the corresponding diamine, (b) by condensation of acrylic acid and a diamine for chelates with propionate arms or (c) by condensation of dihalogen derivatives of the diamine with various amino acids. The quinquedentate ed $3 \mathrm{a}^{3-}$ was prepared by the condensation method, from 1,2-diaminoethane and neutralized chloroacetic acid. ${ }^{5}$ The ligand was isolated as the calcium salt $\mathrm{Ca}_{3}(\mathrm{ed} 3 \mathrm{a})_{2^{-}}$ $\cdot 12 \mathrm{H}_{2} \mathrm{O}$ and transformed in the two complexes (1) and (2) as outlined in Scheme 1. The reaction of $\mathrm{RhCl}_{3} \cdot \mathrm{H}_{2} \mathrm{O}$ and the quinquedentate ed $3 \mathrm{a}^{3-}$ produced a mixture of two complexes, and chromatography was used to separate the two complexes. The mixture was passed through a column of QAE A-25 Sephadex in the $\mathrm{Cl}^{-}$form. The yellow bands with different charges, i.e. neutral cis-equatorial-[Rh(ed3a) $\left.\mathrm{H}_{2} \mathrm{O}\right] \cdot \mathrm{H}_{2} \mathrm{O}(\mathbf{1})$ and anionic cis-equatorial- $\mathrm{Na}[\mathrm{Rh}(\mathrm{ed} 3 \mathrm{a}) \mathrm{Cl}] \cdot \mathrm{H}_{2} \mathrm{O}(2)$, were separated. After desalting by passage through a Sephadex G-10 column, we were able to isolate crystals of (1) and (2) suitable for $\mathrm{X}$-ray analysis, and the complexes were also characterized by elemental analysis, IR, UV-Vis and NMR spectroscopy.

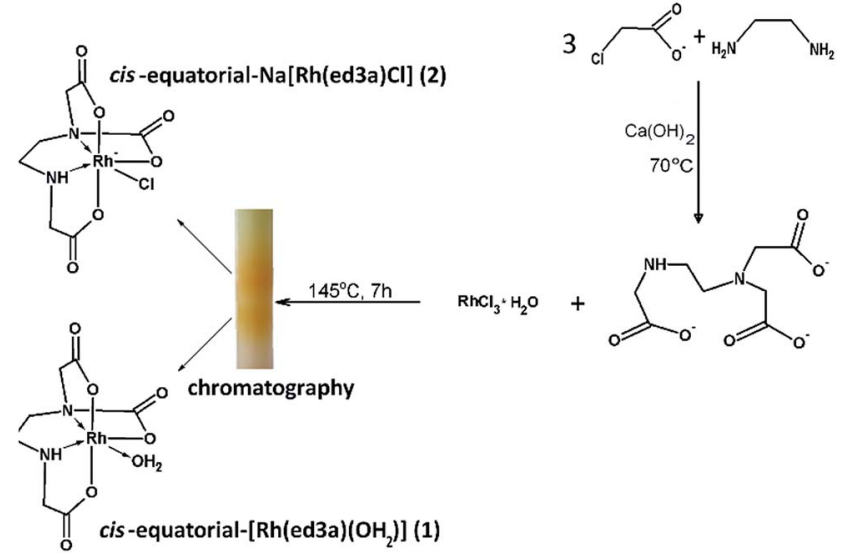

Scheme 1 Synthesis of ed3a ${ }^{3-}$ and the corresponding $\mathrm{Rh}^{\text {III }}$ complexes (1) and (2).

\section{Description of the crystal structures}

A structural diagram of the cis-equatorial-[Rh(ed3a) $\left.\left(\mathrm{OH}_{2}\right)\right] \cdot \mathrm{H}_{2} \mathrm{O}$ (1) and cis-equatorial- $\mathrm{Na}[\mathrm{Rh}($ ed $3 \mathrm{a}) \mathrm{Cl}] \cdot \mathrm{H}_{2} \mathrm{O}$ (2) with the adopted atom-numbering scheme is shown in Fig. 2, along with the packing in the crystals of (1) and (2). Selected bond lengths and valence angles are listed in Table 1.
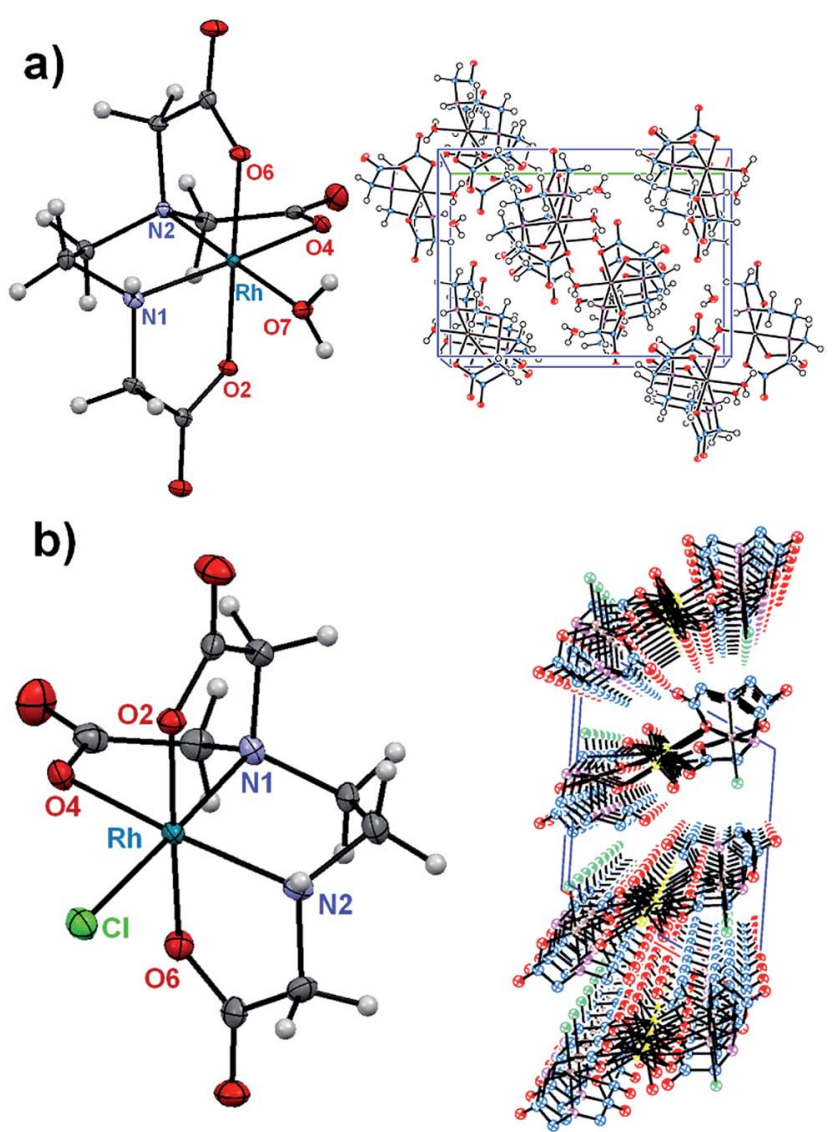

Fig. 2 Ortep diagram of the $\left[\mathrm{Rh}(\mathrm{ed} 3 \mathrm{a})\left(\mathrm{OH}_{2}\right)\right]$ molecular complex (a) and $\left[\mathrm{Rh}(\mathrm{ed} 3 \mathrm{a}) \mathrm{Cl}^{-}\right.$complex anion (b) and crystal packing views along $a$ axis (for $\left[\mathrm{Rh}(\mathrm{ed} 3 \mathrm{a})\left(\mathrm{OH}_{2}\right)\right]$ ) and $b$ axis (for $\left.[\mathrm{Rh}(\mathrm{ed3a}) \mathrm{Cl}]^{-}\right)(50 \%$ probability ellipsoids). 
Table 1 Selected bond distances and angles for $\left[\mathrm{Rh}\left(\right.\right.$ ed3a) $\left.\left(\mathrm{OH}_{2}\right)\right] \cdot \mathrm{H}_{2} \mathrm{O}$ (1) and $\mathrm{Na}[\mathrm{Rh}(\mathrm{ed} 3 \mathrm{a}) \mathrm{Cl}] \cdot \mathrm{H}_{2} \mathrm{O}(2)$
(1)

M-L bond lengths $(\AA)$

\begin{tabular}{|c|c|c|c|}
\hline \multicolumn{4}{|c|}{ M-L bond lengths $(\AA)$} \\
\hline $\mathrm{Rh}-\mathrm{O}(7)$ & $2.072(2)$ & $\mathrm{Rh}-\mathrm{Cl}$ & $2.353(1)$ \\
\hline $\mathrm{Rh}-\mathrm{O}(2)$ & $2.018(2)$ & $\mathrm{Rh}-\mathrm{O}(2)$ & $2.008(3)$ \\
\hline $\mathrm{Rh}-\mathrm{O}(4)$ & $2.050(2)$ & $\mathrm{Rh}-\mathrm{O}(4)$ & $2.074(3)$ \\
\hline $\mathrm{Rh}-\mathrm{O}(6)$ & $2.010(2)$ & $\mathrm{Rh}-\mathrm{O}(6)$ & $2.013(3)$ \\
\hline $\mathrm{Rh}-\mathrm{N}(1)$ & $2.027(2)$ & $\mathrm{Rh}-\mathrm{N}(1)$ & $2.011(4)$ \\
\hline $\mathrm{Rh}-\mathrm{N}(2)$ & $1.996(2)$ & $\mathrm{Rh}-\mathrm{N}(2)$ & $2.031(4)$ \\
\hline
\end{tabular}

Valence angles $\left({ }^{\circ}\right)$

cis angles

$\mathrm{O}(2)-\mathrm{Rh}-\mathrm{O}(4)$

$\mathrm{O}(2)-\mathrm{Rh}-\mathrm{O}(7)$

$\mathrm{O}(2)-\mathrm{Rh}-\mathrm{N}(1)$

$\mathrm{O}(4)-\mathrm{Rh}-\mathrm{O}(7)$

$\mathrm{O}(6)-\mathrm{Rh}-\mathrm{O}(4)$

$\mathrm{O}(6)-\mathrm{Rh}-\mathrm{O}(7)$

$\mathrm{O}(6)-\mathrm{Rh}-\mathrm{N}(1)$

$\mathrm{N}(1)-\mathrm{Rh}-\mathrm{O}(7)$

$\mathrm{N}(2)-\mathrm{Rh}-\mathrm{O}(2)$

$\mathrm{N}(2)-\mathrm{Rh}-\mathrm{O}(4)$

$\mathrm{N}(2)-\mathrm{Rh}-\mathrm{O}(6)$

$\mathrm{N}(2)-\mathrm{Rh}-\mathrm{N}(1)$

trans angles

$\mathrm{O}(6)-\mathrm{Rh}-\mathrm{O}(2)$

$\mathrm{N}(2)-\mathrm{Rh}-\mathrm{O}(7)$

$\mathrm{N}(1)-\mathrm{Rh}-\mathrm{O}(4)$
(2)
91.11(10) 90.05(12) 85.55(14) $95.39(13)$ 97.46(10) 89.99(10) 91.05(12) 83.30(14) 82.97(14) 93.34(14) 86.90(16) 93.02(12)

178.33(13) 176.63(10) $168.09(14)$
A coordination number of six is attained by $\mathrm{Rh}^{\mathrm{III}}$ in both complexes, via three deprotonated oxygen atoms of the carboxylate groups, two nitrogen atoms of the diamine, and the sixth coordination place occupies a water (1) or chloride ligand (2). In the crystals of (1) a hydrogen bonding network is formed, which involves the carboxylate and amino groups of the ed $3 \mathrm{a}^{3-}$ ligand as well as the coordinated and solvent water molecules. In (2) a polymeric structure is formed, with two of the carboxylate groups bridging $\mathrm{Rh}^{\mathrm{III}}$ and $\mathrm{Na}^{+}$. The water molecules are primarily involved in $\mathrm{Na}-\mathrm{O}-\mathrm{Na}$ bridging via their oxygen atoms but further hydrogen bridges are formed to the coordinated chloride and carboxylate ligands. $\mathrm{Na}^{+}$is seven coordinate; intermolecular hydrogen bridges are also formed between amino ( $\mathrm{H}$ donor) and carboxylate groups ( $\mathrm{H}$ acceptor).

The positions of the carboxylate groups define the cis-equatorial geometry. Two acetate R rings (out-of-plane glycinate ring) occupy axial positions and the equatorial plane includes one five-membered acetate $\mathrm{G}$ ring (in-plane glycinate ring), the fivemembered ethylenediamine E ring and a water molecule (1) or chloride ion (2). Complex (1) includes one longer equatorial Rh$\mathrm{O}$ (7) bond (2.072(2) $\mathrm{A}$, to the water ligand), while complex (2) has one longer Rh-Cl bond (2.353(1) $\mathrm{A})$. The other metal-donor distances are within the expected range of 1.996(2) A to 2.050(2)

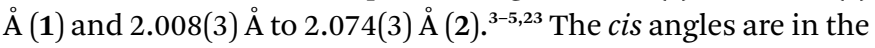
range of $83.0(7)^{\circ}$ to $98.6(7)^{\circ}$ for $(1)$ and $83.0(1)^{\circ}$ to $97.4(1)^{\circ}$ for $(2)$, and the trans angles vary between $169.0(8)^{\circ}$ and $178.6(7)^{\circ}$ for $(1)$ and $168.1(1)^{\circ}$ and $178.3(1)^{\circ}$ for (2). The equatorial ethylenediamine (E) ring is in an envelope conformation. The puckering parameters $q 2$ and $\varphi 2$ (the ideal values for an envelope conformation are $q 2>0 \AA, \varphi 2=0^{\circ}$, and for a twisted conformation $\left.q 2>0 \AA, \varphi 2=90^{\circ}[\pi / 2]\right),{ }^{24}$ which relate to deviations of the ring atoms from the mean plane, are $q 2=0.443(1) \AA$ and $\varphi 2$ $=281.0(2)^{\circ}$ for $(1)$ and $q 2=0.455(2) \AA$ and $\varphi 2=259.1(3)^{\circ}$ for $(2)$. The three five-membered acetate rings have a twisted conformation in (1). Their puckering parameters are $q 2=0.433(5) \AA$, $\varphi 2=153.1(7)^{\circ}\left(\mathrm{RhO}_{4} \mathrm{C}_{6} \mathrm{C}_{5} \mathrm{~N}_{2}\right) ; q 2=0.301(0) \AA, \varphi 2=159.1(6)^{\circ}$ $\left(\mathrm{RhO}_{2} \mathrm{C}_{1} \mathrm{C}_{2} \mathrm{~N}_{1}\right)$ and $q 2=0.087(4) \AA, \varphi 2=228.8(0)^{\circ}\left(\mathrm{RhO}_{6} \mathrm{C}_{8} \mathrm{C}_{7^{-}}\right.$ $\mathrm{N}_{2}$ ). In complex (2), one of the axial five-membered acetate rings is nearly planar and the second adopts an envelope conformation ( $\mathrm{R}$ rings). The equatorial acetate ring $(\mathrm{G})$ is in an envelope conformation. The puckering parameters are: $q 2=0.416(8) \AA$, $\varphi 2=147.6(2)^{\circ}\left(\mathrm{RhO}_{4} \mathrm{C}_{4} \mathrm{C}_{3} \mathrm{~N}_{1}\right) ; q 2=0.290(8) \AA, \varphi 2=171.3(4)^{\circ}$ $\left(\mathrm{RhO}_{6} \mathrm{C}_{8} \mathrm{C}_{7} \mathrm{~N}_{2}\right)$.

\section{Spectroscopic analysis}

IR spectroscopy. The asymmetric stretching frequencies of the carboxylate have been used as criterion for distinguishing between protonated (1700-1750 $\left.\mathrm{cm}^{-1}\right)$ and coordinated carboxylate (1560-1680 cm $\left.\mathrm{cm}^{-1}\right) .{ }^{5}$ The vibration of five-membered rings is at higher energy (1600-1680 $\left.\mathrm{cm}^{-1}\right)$ than the corresponding vibration of six-membered chelate rings (1560-1600 $\left.\mathrm{cm}^{-1}\right) .{ }^{5}$ Complex (1) shows one strong peak at $1631 \mathrm{~cm}^{-1}$, and this is assigned to an asymmetric vibration of the fivemembered acetate rings (Fig. S1, ESI $\dagger$ ). Complex (2) shows one very strong peak at $1630 \mathrm{~cm}^{-1}$, assigned to the carboxylate group of the five-membered rings, and the weak peak at 1680 $\mathrm{cm}^{-1}$ indicates a cis-equatorial isomer (Fig. S2, ESI $\dagger$ ). The absence of other vibrations in the $1700-1750 \mathrm{~cm}^{-1}$ area suggests that all carboxylate groups are coordinated.

Electronic spectroscopy. Data of the UV-Vis spectra of (1) and (2) are presented in Table 2 and Fig. 3. For comparison, the transitions of $\left[\mathrm{Rh}(\mathrm{Hedta})\left(\mathrm{OH}_{2}\right)\right](3)$, with a 5-coordinate Hedta $^{3-}$, are also tabulated. ${ }^{23}$ The shapes of the electronic spectra of (1), (2) and (3) are different to previously examined $\mathrm{Rh}^{\mathrm{III}}$ complexes ${ }^{25}$ and show two almost symmetrical bands, arising from spin-allowed transitions. Although the complexes have $C_{1}$ symmetry, their electronic spectra have only one component in the region of the lower energy ${ }^{1} \mathrm{~T}_{1 \mathrm{~g}}\left(O_{\mathrm{h}}\right)$ transition, and there is no splitting of the higher energy ${ }^{1} \mathrm{~T}_{2 \mathrm{~g}}\left(O_{\mathrm{h}}\right)$ absorption band. In holohedrized $\left(O_{\mathrm{h}}\right)$ symmetry only one component is predicted in this region for complexes of edta-

Table 2 UV-Vis data of Rh-ed3a-type of complexes

\begin{tabular}{lllll}
\hline & \multicolumn{3}{l}{ Wavelength/energy } & \\
\cline { 2 - 4 } & $\mathrm{nm}$ & $10^{3} \nu\left(\mathrm{cm}^{-1}\right)$ & $\varepsilon\left(\mathrm{L} \mathrm{mol}^{-1} \mathrm{~cm}^{-1}\right)$ & Assignment $^{a}$ \\
\hline (1) & $353^{b}$ & 28.33 & 405.59 & $O_{\mathrm{h}}$ \\
& 294 & 34.01 & 326.51 & $\mathrm{I}^{1} \mathrm{~A}_{1 \mathrm{~g}} \rightarrow{ }^{1} \mathrm{~T}_{1 \mathrm{~g}}$ \\
(2) & $373^{b}$ & 26.81 & 512.13 & $\mathrm{II}^{1} \mathrm{~A}_{1 \mathrm{~g}} \rightarrow{ }^{1} \mathrm{~T}_{2 \mathrm{~g}}$ \\
& 307 & 32.57 & 447.77 & $D_{4 \mathrm{~h}}$ \\
(3) & $371^{c}$ & 26.95 & 275.00 & I $O_{\mathrm{h}} \rightarrow{ }^{1} \mathrm{~A}_{2 \mathrm{~g}},{ }^{1} \mathrm{E}_{\mathrm{g}}{ }^{a}$ \\
& 301 & 33.22 & 265.00 & II $O_{\mathrm{h}} \rightarrow{ }^{1} \mathrm{~B}_{2 \mathrm{~g}},{ }^{1} \mathrm{E}_{\mathrm{g}}{ }^{b}$
\end{tabular}

${ }^{a}$ For all complexes. ${ }^{b}$ This work. ${ }^{c}$ Ref. 23. 


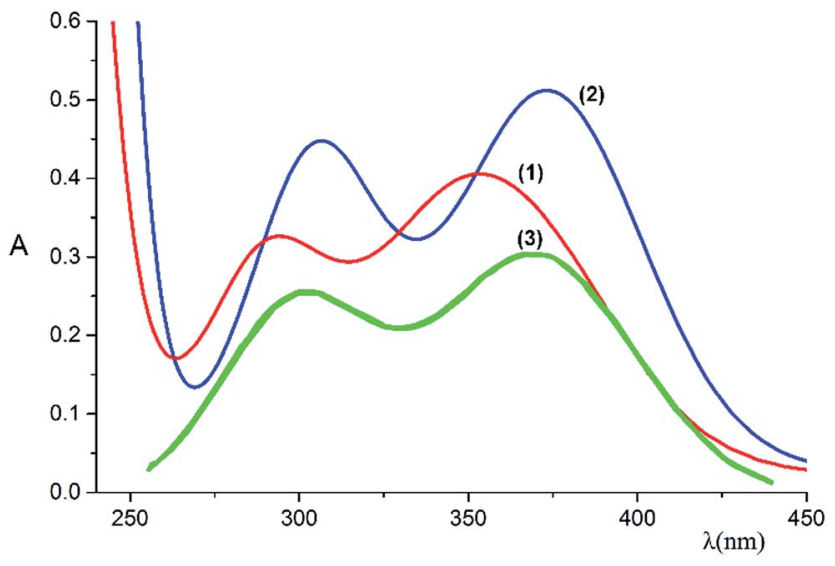

Fig. 3 Electronic absorption spectra of $\mathrm{Rh}^{\text {III }}$ complexes in aqueous solution: _-__- $\left[\mathrm{Rh}(\mathrm{ed} 3 \mathrm{a})\left(\mathrm{OH}_{2}\right)\right] \cdot \mathrm{H}_{2} \mathrm{O}(1), \ldots$ (2), _-_-_ $\left[\mathrm{Rh}(\mathrm{Hedta})\left(\mathrm{OH}_{2}\right)\right]$ (3).

type ligands. ${ }^{1}$ The absorption maxima of (1) are shifted to higher energy relative to (2), and this is expected from the relatively long equatorial $\mathrm{Rh}-\mathrm{Cl}$ bond (2.353(1) $\mathrm{A})$ in (2), leading to a lower in-plane ligand field for the chlorido complex.

NMR spectroscopy. The NMR spectra are discussed in accordance with published data. ${ }^{1}$ A typical ${ }^{1} \mathrm{H}$ NMR spectrum of $\mathrm{Na}[\mathrm{Rh}(\mathrm{ed} 3 \mathrm{a}) \mathrm{Cl}] \cdot \mathrm{H}_{2} \mathrm{O}(2)$ is given in Fig. 4 . It consists of a singlet for acetate at $3.99 \mathrm{ppm}$ and two $\mathrm{AB}$ signals (4.08-3.38 ppm) for acetate as well as several resonances at lower field for the ethylene group.

Some of the latter resonances (a complex ABCD pattern) are superimposed on the AB-type resonances of acetate. The tentative assignment of the low-field part of the $\mathrm{AB}$ pattern is complicated by the superposition with the singlet, obscuring one of the resonances. The symmetry of the molecule, assuming cis-equatorial configuration (see Fig. 1), with two acetate R rings
( $\mathrm{R}_{1}$ and $\mathrm{R}_{2}$ above and below the $\mathrm{Rh}$-ed3a nitrogen plane) and one $\mathrm{G}$ ring in the $\mathrm{Rh}$-ed3a nitrogen plane, should result in three different acetate-type $\mathrm{AB}$ signals.

If the chemical shifts of two acetate protons on one of the rings are very similar, as might be expected for $R_{1}$, the $A B$ pattern collapses into a strong signal with very weak side peaks. Two acetate protons on $\mathrm{R}_{2}$ (Fig. 4) are symmetric with respect to the $\mathrm{C}-\mathrm{N}$ bond in this ring and experience nearly identical shielding by the $\mathrm{C}-\mathrm{N}$ bonds of the $\mathrm{G}$ and $\mathrm{E}$ rings. Therefore, the splitting of these two protons should be minimal. The collapsed $\mathrm{AB}$ pattern appearing as a single absorption at $3.99 \mathrm{ppm}$ is attributed to this effect, and the weak side peaks can in fact be observed. The ${ }^{1} \mathrm{H}$ NMR spectrum of (1) does not differ significantly from that in Fig. 4, except that the collapsed singlet at $4.05 \mathrm{ppm}$ along with the weak side peaks at $4.02 \mathrm{ppm}$ shows reversed shifts (Fig. S3, ESI $\dagger$ ). Further, Fig. S4 (ESI $\dagger$ ) and S5 $(\mathrm{ESI} \dagger)$ show the corresponding ${ }^{13} \mathrm{C}$ NMR spectra.

\section{Solution studies}

Protonation equilibria of ed $3 \mathbf{a}^{3-}$. The protonation constants $\left(\log K_{i}^{\mathrm{H}}\right)$ of ed3a were determined by $\mathrm{pH}$ potentiometry and are reported in Table 3 together with those of edta for comparison (standard deviations in parentheses). The protonation constants are defined by eqn (1):

$$
K_{i}^{\mathrm{H}}=\frac{\left[\mathrm{H}_{i} \mathrm{~L}\right]}{\left[\mathrm{LH}_{i-1}\right]\left[\mathrm{H}^{+}\right]} ; \quad i=1,2,3 \ldots
$$

The first two protonation events occur at the nitrogen atoms and the $\log K_{1}^{\mathrm{H}}$ and $\log K_{2}^{\mathrm{H}}$ values were found to be 9.72 and 5.81 . The $\log K_{3}^{\mathrm{H}}$ value (2.89) corresponds to the protonation of a carboxylate. The $\log K_{4}^{\mathrm{H}}$ and $\log K_{5}^{\mathrm{H}}$ values of two additional carboxylate groups are below 2 and could therefore not be determined potentiometrically. A comparison of the

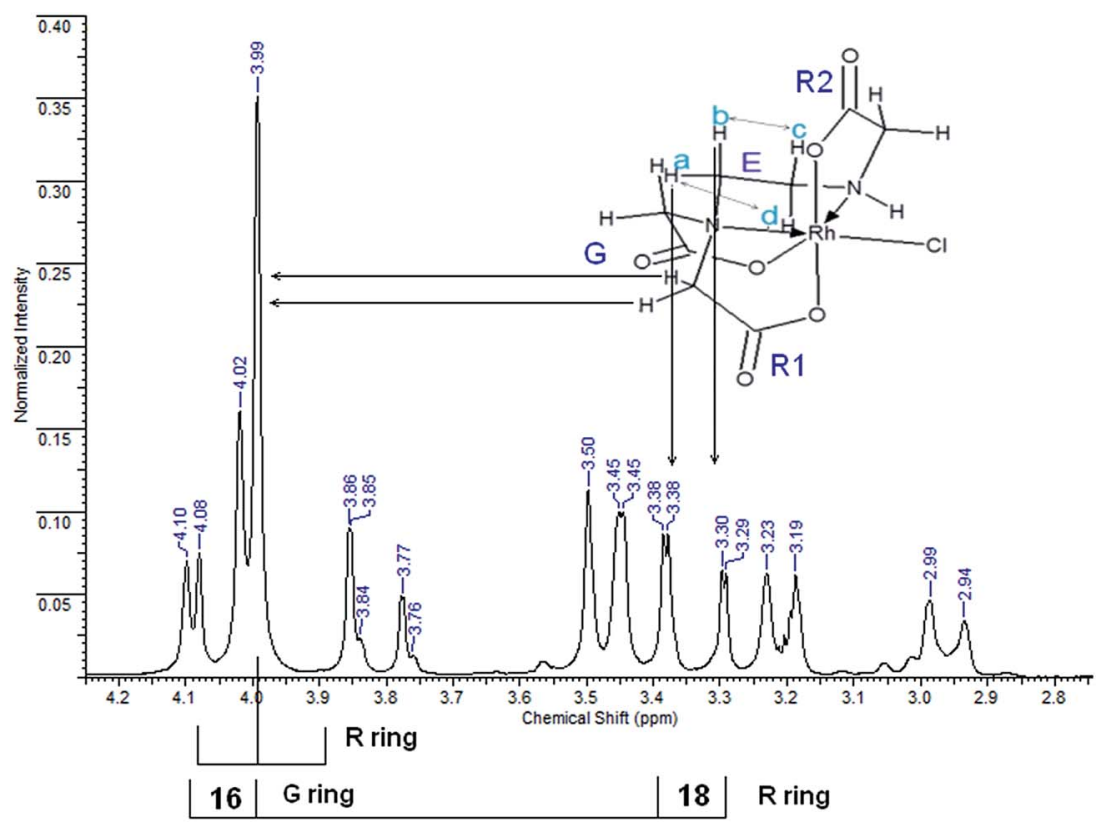

Fig. $4{ }^{1} \mathrm{H}$ NMR spectrum of $[\mathrm{Rh}(\mathrm{ed} 3 \mathrm{a}) \mathrm{Cl}]^{-}$. 
Table 3 Protonation constants of ed3a

\begin{tabular}{lll}
\hline & ed3a & \\
\hline Ionic strength & $0.1 \mathrm{M} \mathrm{NaCl}$ & \\
$\log K_{1}^{\mathrm{H}}$ & $9.72(2)$ & $0.1 \mathrm{M} \mathrm{KCl}$ \\
$\log K_{2}^{\mathrm{H}}$ & $5.81(3)$ & 10.19 \\
$\log K_{3}^{\mathrm{H}}$ & $2.89(3)$ & 6.16 \\
& & 2.69
\end{tabular}

${ }^{a}$ Ref. 26

protonation constants of ed $3 \mathrm{a}^{3-}$ and edta ${ }^{4-}$ obtained in similar media reveals that the $\log K_{3}^{\mathrm{H}}$ values are similar but the $\log K_{1}^{\mathrm{H}}$ and $\log K_{3}^{\mathrm{H}}$ are significantly different. The first and second protonation constants of ed $3 \mathrm{a}^{3-}$ are lower by 0.47 and $0.35 \log K$ units than those of edta ${ }^{4-}$, which can be explained by one additional acetate group in edta ${ }^{4-}$. The acetate group with its positive inductive effect reduces the acidity of the proton at an amine nitrogen atom.

The distribution diagram of ed $3 \mathrm{a}^{3-}$ is given in Fig. S6 (ESI $\dagger$ ). The fully deprotonated species, ed $3 \mathrm{a}^{3-}$ exists in solution at $\mathrm{pH}$ higher than 7. Protonated species Hed $3 \mathrm{a}^{2-}, \mathrm{H}_{2} \mathrm{ed} 3 \mathrm{a}^{-}$and $\mathrm{H}_{3}$ ed3a are present in solution from $\mathrm{pH} 2$ to 12 .

Complex formation equilibria of $\mathrm{Rh}^{\mathrm{III}}$ with ed $3 \mathrm{a}^{3-}$

Potentiometric titrations. The conditional stability constants of the $\mathrm{Rh}^{\mathrm{III}}$ complex with $\mathrm{H}_{3}$ ed3a were determined potentiometrically at $25{ }^{\circ} \mathrm{C}$ in $0.1 \mathrm{M}$ aqueous $\mathrm{NaCl}$. The experimental data obtained are shown in Fig. S7 (ESI $\dagger$ ).

To find the model that gives the best fit to the experimental data, various complexes and combinations thereof were included in Hyperquad2006 calculations. ${ }^{27}$ The model selected was that which gave the best statistical fit and which was chemically consistent with the titration data. ${ }^{28}$ The sample standard deviation, $s$, and the $\chi^{2}$-statistics were used as criteria for the selection of the complex models. The results obtained are listed in Table 4.

Spectrophotometric titrations. Spectrophotometric data were obtained from $\mathrm{Rh}^{\mathrm{III}}$-ed3a solutions, cooled to $25{ }^{\circ} \mathrm{C}$, where both $\mathrm{Rh}^{\mathrm{III}}$ and ed3a concentrations were kept constant, while the $\mathrm{pH}$ was varied by addition of standard $\mathrm{HCl}$ or $\mathrm{NaOH}$ solutions, as appropriate. All corresponding UV-Vis spectra are presented in Fig. S8-S12, ESI. $\uparrow$ The spectroscopic data were evaluated with the HypSpec2014 program, ${ }^{29}$ where the complexes found by potentiometry were included in HypSpec calculations, and the corresponding conditional stability constants were optimized. The resulting parameters are given in Table 4 .

The distribution diagram of the $\mathrm{Rh}^{\mathrm{III}}-\mathrm{ed} 3 \mathrm{a}^{3-}$ system (concentration ratio $[\mathrm{ed} 3 \mathrm{a}] /[\mathrm{Rh}]=3: 1$ ) is shown in Fig. 5 . The dominating complex at low $\mathrm{pH}$ values is $[\mathrm{Rh}(\operatorname{Hed} 3 \mathrm{a})]^{+}$with the maximum concentration of $45 \%$ at $\mathrm{pH}=6.3$.

$$
\begin{aligned}
& \mathrm{Rh}^{\mathrm{III}}+\mathrm{H}_{2} \mathrm{ed}_{3} \mathrm{a}^{-} \leftrightarrows[\mathrm{Rh}(\mathrm{Hed} 3 \mathrm{a})]^{+}+\mathrm{H}^{+} ; \beta \\
& \log \beta=\log \beta_{1,1,1}-\log K_{1}^{\mathrm{H}}=12.16-9.72=2.44
\end{aligned}
$$

The conditional stability constant $(\log \beta=2.44)$ implies that one nitrogen and carboxylate oxygen donors do not coordinate to rhodium in $[\mathrm{Rh}(\mathrm{Hed} 3 \mathrm{a})]^{+}$(Scheme 2). Here, two pathways are proposed for the formation of complexes in solution, i.e. $1 \rightleftarrows 2$
Table 4 Conditional stability constants of $\mathrm{Rh}^{\text {III }}-\mathrm{ed3} \mathrm{a}^{3-}$ complexes

\begin{tabular}{|c|c|c|c|}
\hline & \multicolumn{3}{|l|}{$\underline{\log \beta_{p, q, r} \pm \sigma}$} \\
\hline & \multirow{2}{*}{$\frac{\text { Potentiometric }}{25{ }^{\circ} \mathrm{C}}$} & \multicolumn{2}{|c|}{ Spectrophotometric } \\
\hline & & $25^{\circ} \mathrm{C}$ & After heating \\
\hline$[\mathrm{Rh}(\mathrm{Hed} 3 \mathrm{a})]^{+}$ & $12.16(4)$ & $12.39(8)$ & $12.54(9)$ \\
\hline$[\operatorname{Rh}($ ed $3 a)]$ & $5.18(3)$ & $5.26(6)$ & $7.26(3)$ \\
\hline$\left[\operatorname{Rh}(\text { ed } 3 a)_{2}\right]^{3-}$ & $8.87(8)$ & $8.18(12)$ & - \\
\hline$[\mathrm{RhOH}(\mathrm{ed} 3 \mathrm{a})]^{-}$ & $-2.93(5)$ & $-3.04(7)$ & - \\
\hline Statistics & $\chi^{2}=11.28, s=1.50$ & $s=0.032$ & $s=0.024$ \\
\hline
\end{tabular}
formed in $0.1 \mathrm{M} \mathrm{NaCl}^{\text {ionic medium }}{ }^{a}$

${ }^{a}$ The water/chloride exchange in $\mathrm{Rh}^{\mathrm{III}}$ complex is likely to occur, ${ }^{18 d, 30}$ accordingly in the formulas, the water or $\mathrm{Cl}^{-}$monodentates are omitted.

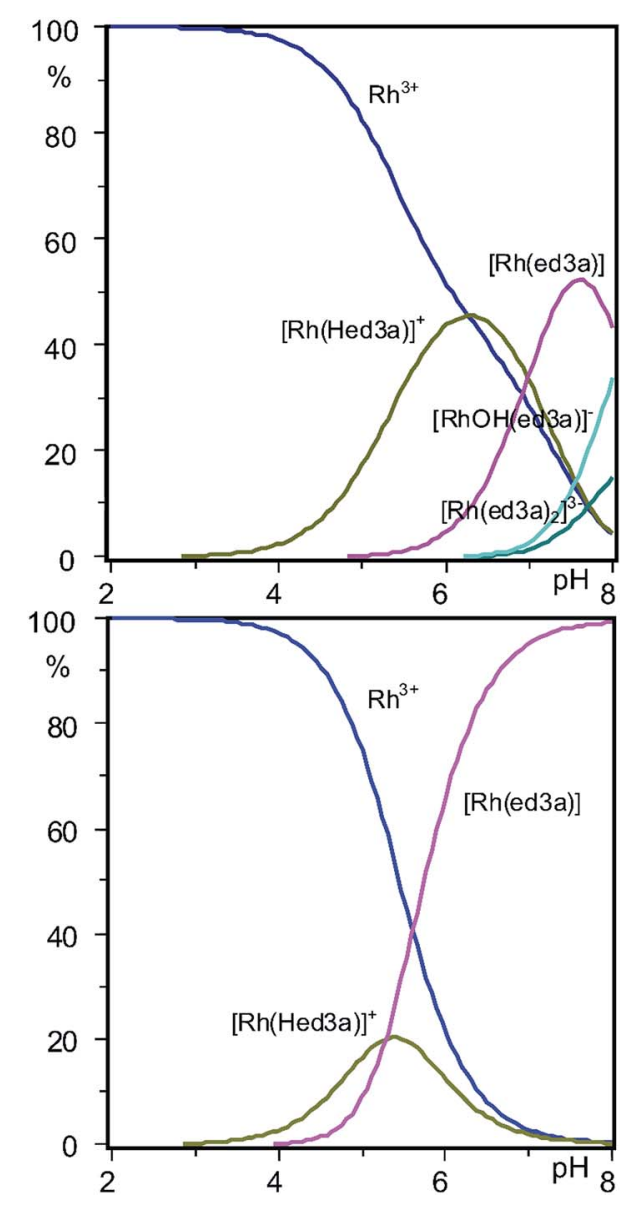

Fig. 5 Concentration distribution diagrams of $\mathrm{Rh}^{\text {III-ed3a }} \mathrm{a}^{3-}$ complexes at concentrations of $2.0 \mathrm{mM}$ for $\mathrm{Rh}^{\mathrm{III}}, 6.0 \mathrm{mM}$ for ed3a ${ }^{3-}$ and $100.0 \mathrm{mM} \mathrm{NaCl}$, obtained by: (top) potentiometry and spectrophotometry at $25^{\circ} \mathrm{C}$; (bottom) spectrophotometry after heating in a closed vessel to $145^{\circ} \mathrm{C}$ (see Experimental).

$\rightleftarrows 4$ and $1 \rightleftarrows 2 \rightleftarrows 3$. The first pathway emerges from the results of the potentiometric and spectrophotometric titration, while the second describes the results of the spectrophotometric titration after heating in a closed vessel to $145^{\circ} \mathrm{C}$.

With increasing $\mathrm{pH}[\mathrm{Rh}(\operatorname{Hed} 3 \mathrm{a})]^{+}$releases a proton (the equilibrium $1 \rightleftarrows 2 \rightleftarrows 4$ ), and forms [Rh(ed3a)] in which the 
ed $3 \mathrm{a}^{3-}$ is fully deprotonated, with a maximum of $52 \%$ concentration at $\mathrm{pH}=7.6$ (Fig. 5 and Scheme 2). The equilibrium constant, $K_{1}$, for this reaction may be calculated from the overall conditional stability constants of $[\mathrm{Rh}(\mathrm{Hed} 3 \mathrm{a})]^{+}$and $[\mathrm{Rh}(\mathrm{ed} 3 \mathrm{a})], \log K_{1}=\log \beta_{1,1,1}-\log \beta_{1,0,1}=12.16-5.18=6.98$. This value is similar to the protonation constant $\log K_{2}^{\mathrm{H}}$. This means that the amine nitrogen loses a proton and coordinates to rhodium(III). Since the stability of the $[\mathrm{Rh}(\mathrm{ed} 3 \mathrm{a})]$ is small $\left(\log \beta_{1,0,1}=5.18\right)$, the remaining free carboxylate group of ed $3 \mathrm{a}^{3-}$ is only weakly coordinated to rhodium(III). The equilibrium constant, $\log K$, for the model $1 \rightleftarrows 2 \rightleftarrows 3$ is 5.28 which is similar to $\log K_{2}^{\mathrm{H}}$ (see Table 3 ). After heating the solution of complex 2 (Scheme 2), the monodentate donor $\mathrm{X}$ is replaced by the $\mathrm{COO}^{-}$group, and the formation of a quinquedentate ligand complex with rhodium(III) and ed3a occurs. The equilibrium constant (equilibrium $2 \rightleftarrows 3$ ) $\log K_{\text {aq }}=2.08$ can be compared with the formation constant of a hexacoordinated complex between rhodium(III) and EDTA. ${ }^{31}$

Upon increasing the pH (the model $1 \rightleftarrows 2 \rightleftarrows 4$ ), $\left[\mathrm{Rh}(\mathrm{ed} 3 \mathrm{a})\left(\mathrm{H}_{2} \mathrm{O}\right) \mathrm{X}\right]$ releases a proton and forms [ $\left.\mathrm{RhOH}(\mathrm{ed} 3 \mathrm{a}) \mathrm{X}\right]$, which begins to form at $\mathrm{pH}=6.2$, and its concentration increases with further increase of $\mathrm{pH}$. The complex [RhO$\mathrm{H}(\mathrm{ed} 3 \mathrm{a}) \mathrm{X}]$, upon increasing of $\mathrm{pH}$, binds another $\mathrm{Hed}_{3} \mathrm{a}^{2-}$ ligand and forms $\left[\mathrm{Rh}(\mathrm{ed} 3 \mathrm{a})_{2}\right]^{3-}$ (see Fig. 5 and S6, ESI $\dagger$ ):

$$
[\mathrm{RhOH}(\mathrm{ed} 3 \mathrm{a}) \mathrm{X}]+\mathrm{Hed} 3 \mathrm{a}^{2-}=\left[\mathrm{Rh}(\mathrm{ed} 3 \mathrm{a})_{2}\right]^{3-}+\mathrm{H}_{2} \mathrm{O}+\mathrm{X}
$$

$\left[\mathrm{Rh}(\mathrm{ed} 3 \mathrm{a})_{2}\right]^{3-}$ starts to form at $\mathrm{pH} 6.5$ and has a maximum concentration at $\mathrm{pH}=9$. Our current research deals with complexes with $\mathrm{pd}^{3} \mathrm{a}^{3-}$ ligand (pd3a stands for propanediamine-

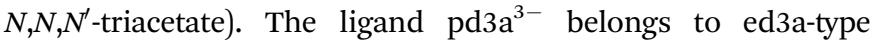
chelates. The $\left[\mathrm{Rh}(\mathrm{pd} 3 \mathrm{a})_{2}\right]^{3-}$ complex was isolated and its structure was confirmed by X-ray analysis. However, these results have not been published yet (Jeremić et al., unpublished results). Bearing that in mind, we believe that existence of $\left[\mathrm{Rh}(\mathrm{ed} 3 \mathrm{a})_{2}\right]^{3-}$ is highly probable as well.

\section{Computational chemistry}

DFT calculations. Computational methods have been used to interpret the experimentally observed structural properties of

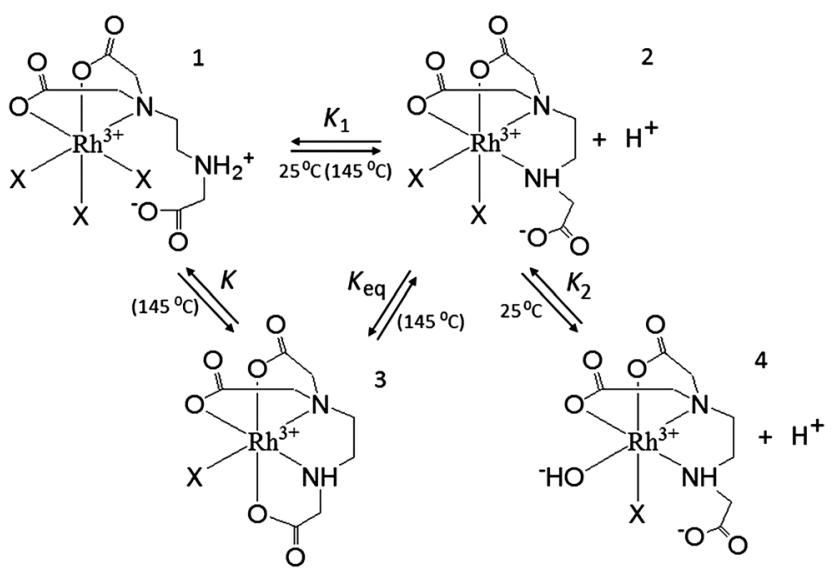

Scheme 2 Dissociation of $\left[\mathrm{Rh}(\mathrm{Hed3a}) \mathrm{X}_{3}\right]^{+} . \mathrm{X}=\mathrm{H}_{2} \mathrm{O}$ or $\mathrm{Cl}^{-}$.

the two complexes of rhodium(III) and possible isomers. Therefore, we have optimized the geometries of the three geometric isomers (cis-equatorial, cis-polar and trans-equatorial, Fig. 1) of the two complexes, using DFT (density functional theory as implemented in Gaussian 09). ${ }^{32}$ The results for both complexes determine the cis-equatorial isomer as the most energetically stable one, by $13.4 \mathrm{~kJ} \mathrm{~mol}^{-1}$ for the chloro complex (1) and by $14.6 \mathrm{~kJ} \mathrm{~mol}^{-1}$ for the aqua complex (2) (see Table 5).

Table 6 contains selected geometric parameters for the optimized structures of (1) and (2), comparing experimental, DFT and force field data of $\mathrm{Rh}-\mathrm{N}$ in-plane, $\mathrm{Rh}-\mathrm{O}$ in-plane, $\mathrm{Rh}-\mathrm{O}$ axial bonds, the averaged coordination cis- and trans-angles and the averaged $\mathrm{Rh}-\mathrm{O}-\mathrm{C}$ angles. It emerges that the observed bond lengths and angles are in excellent agreement with the experimental structures.

Molecular mechanics (force field) calculations. Molecular mechanics (MM) is based on a classical parameterization of non-classical effects for the calculation of molecular structure. The relative energies of the three isomers each of the two complexes, obtained by MM and using the MOMEC software and force field (see Table 5; see Experimental section for modifications of the published force field), ${ }^{33,34}$ and the corresponding structural data (see Table 6) are in very good

Table 5 Comparison of DFT and MM calculated energies for complexes (1) and (2)

DFT MM

\begin{tabular}{lllll} 
Geometrical isomer & $(1)$ & $(2)$ & $(1)$ & $(2)$ \\
\hline cis-Equatorial & $0^{a}$ & $0^{a}$ & $0^{a}$ & $0^{a}$ \\
trans-Equatorial & 13.4 & 14.6 & 1.4 & 1.9 \\
cis-Polar & 33.5 & 21.8 & 4.8 & 4.7
\end{tabular}

${ }^{a}$ The cis-equatorial isomer at the global minimum is assigned an energy of $0 \mathrm{~kJ} \mathrm{~mol}^{-1}$.

Table 6 Comparison of experimental (X-ray), DFT (B3LYP/def2-TZVP) and MM (MOMEC) structural data for $\left[\mathrm{Rh}(\mathrm{ed} 3 \mathrm{a})\left(\mathrm{OH}_{2}\right)\right] \cdot \mathrm{H}_{2} \mathrm{O}(1)$ and $\mathrm{Na}$ $[\mathrm{Rh}(\mathrm{ed} 3 \mathrm{a}) \mathrm{Cl}] \cdot \mathrm{H}_{2} \mathrm{O}(2)$

X-ray : DFT : MM

(1)

\begin{tabular}{lll}
\hline Rh-N $(\AA)$ in-plane & $1.996: 2.015: 2.055$ & $2.011: 2.055: 2.054$ \\
& $2.027: 2.084: 2.061$ & $2.033: 2.075: 2.062$ \\
Rh-O $(\AA)$ in-plane & $2.050: 2.043: 2.004$ & $2.074: 2.063: 2.004$ \\
& $2.072: 2.143: 2.018^{a}$ & - \\
Rh-O $(\AA)$ axial & $2.018: 2.039: 2.001$ & $2.008: 2.046: 1.999$ \\
& $2.010: 2.020: 1.996$ & $2.013: 2.035: 1.994$ \\
Rh-Cl $(\AA)$ & - & $2.353: 2.399: 2.363$ \\
Rh-O-C $\left(^{\circ}\right)^{b}$ & $112.7: 114.3: 113.0$ & $112.8: 114.5: 112.9$ \\
cis-ang. $\left({ }^{\circ}\right)^{b}$ & $90.0: 90.0: 90.1$ & $90.0: 90.0: 90.1$ \\
trans-ang. $\left({ }^{\circ}\right)$ & $178.6: 178.0: 176.3$ & $178.3: 176.2: 176.1$ \\
& $176.8: 177.4: 174.6$ & $176.6: 176.9: 173.2$ \\
& $169.0: 168.1: 167.0$ & $168.2: 166.8: 166.8$ \\
RMSD $(\AA)^{c}$ & 0.0700 & 0.0910
\end{tabular}

${ }^{a}$ Water molecule. ${ }^{b}$ Average value. ${ }^{c}$ RMSD values have been calculated on heavy atoms of overlaid X-ray and MOMEC optimized geometries. 
agreement with the experimental data and the DFT results. Corresponding overlay plots are shown in Fig. 6.

From MM as well as from DFT it emerges that, as expected from a large body of data of aminocarboxylate ligands coordinated to transition metal complexes (see Introduction), the observed cis-equatorial isomer is the most stable. MM suggests that the minima are more shallow than those predicted by DFT and that it might be possible to isolate other isomers. However, isomer conversion is slow for an inert metal center such as $\mathrm{Rh}^{\mathrm{III}}$, and for the biological tests reported below, the isomer observed experimentally in the solid state is the only relevant species.

All three possible structures of the (1) and (2) are chiral (see Fig. 1) and therefore may adopt $\Lambda$ or $\Delta$ configuration and

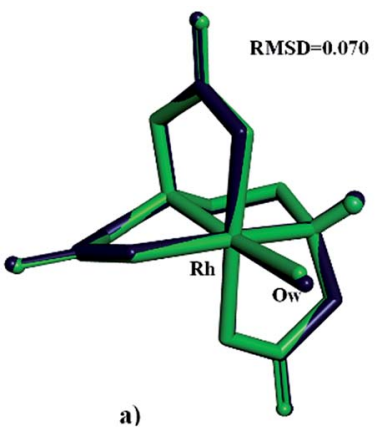

a)

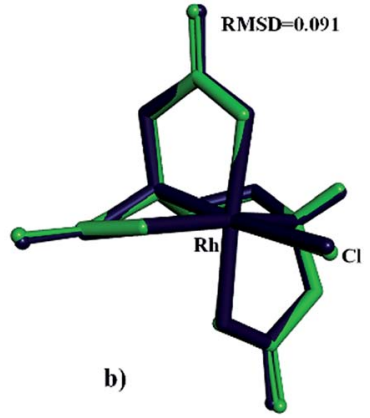

Fig. 6 An overlay of X-ray and MOMEC optimized structures for $\left[\mathrm{Rh}(\mathrm{ed} 3 \mathrm{a})\left(\mathrm{OH}_{2}\right)\right](\mathrm{a})$ and $[\mathrm{Rh}(\mathrm{ed} 3 \mathrm{a}) \mathrm{Cl}]^{-}$(b) complexes: blue = MOMEC optimized structures, green $=\mathrm{X}$-ray structures. therefore increase the number of possible isomers by a factor of 2. Also, the diaminoethane five-membered chelate ring may adopt $\lambda$ or $\delta$ conformation, and this may also increase the number of isomers. However, changing the absolute configuration requires the inversion of $\mathrm{N}$ atoms and therefore a ligand exchange, which is not likely to occur around an inert rhodiu$\mathrm{m}$ (III) center. Conformational flexibility is not unlikely but is a fast process with energy barriers in the $20 \mathrm{~kJ} \mathrm{~mol}^{-1}$ range. It therefore appears that these isomeric possibilities are not of importance for the biological tests reported below, i.e. the only relevant structures are those observed by experiment.

\section{Biological tests}

Antiproliferative activity may results from cytostatic (effect on cell cycle) or cytotoxic effects and both can contribute to apoptosis. The Bcl-2 family of proteins are crucial in the regulation of apoptotic processes. Apoptosis depends on the balance between pro- and anti-apoptotic Bcl-2 proteins. The antiapoptotic protein Bcl-2 plays a key role in apoptosis. Its suppressive activity in apoptotic process may contribute to drug resistance of tumor cells. ${ }^{35-37}$

In vitro antitumor activity. The cytotoxic activity of the new $\mathrm{Rh}^{\mathrm{III}}$ complexes, doxorubicin and cisplatin was evaluated after $48 \mathrm{~h}$ by the MTT assay against four human cancer (MCF-7, A549, HT-29 and HeLa) and one human normal cell line (MRC-5). The commercial antitumor agents doxorubicin and cisplatin were used as reference. The antiproliferative effects were linear and dose-dependent. The cytotoxicity of (1) and (2) against HeLa
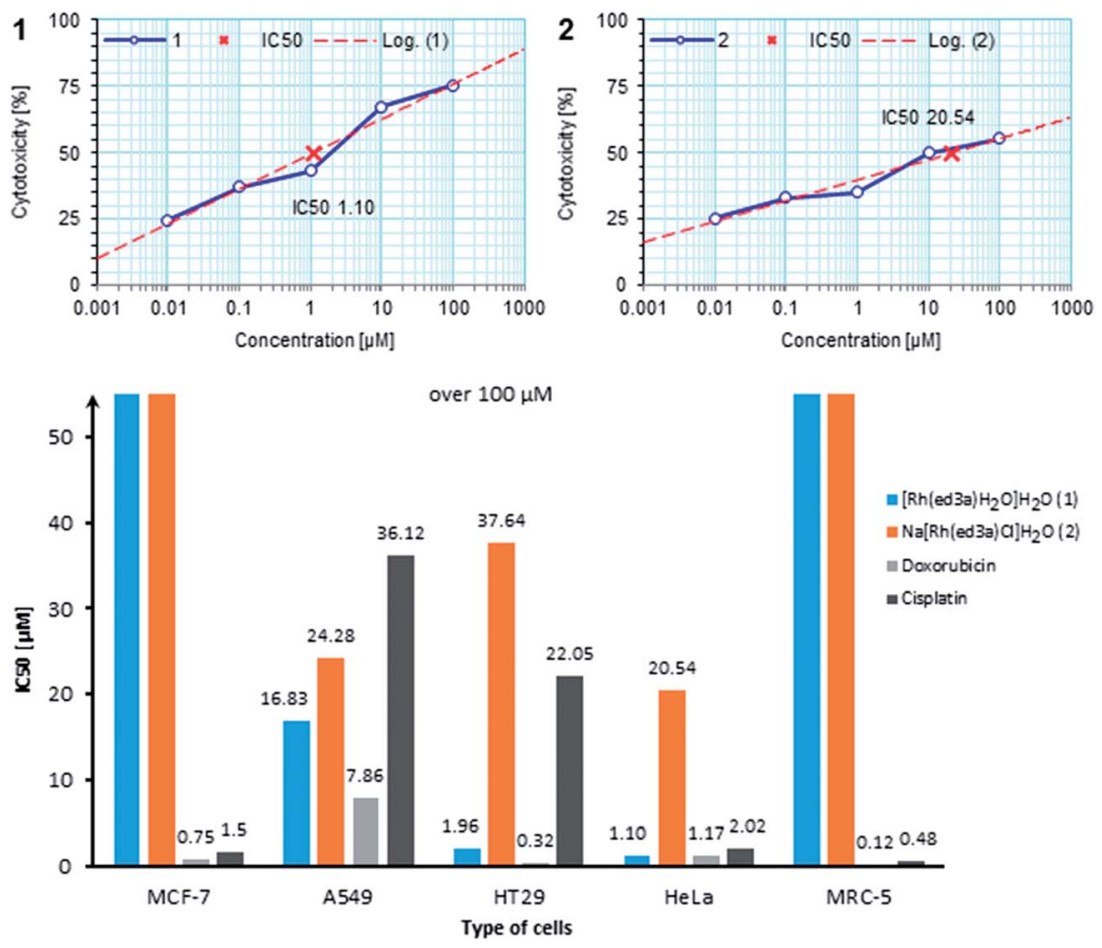

Fig. 7 Linear and dose-dependent cytotoxic effect of complexes (1) and (2) against HeLa cells through the range of applied concentrations and graphical presentation of $\mathrm{IC}_{50}$ values (50\% growth inhibitory concentration, $\mu \mathrm{M}$ ) of selected $\mathrm{Rh}{ }^{\text {III }}$ complexes, doxorubicin and cisplatin for a set of malignant cells and MRC-5 cell line; each point is the mean of two independent experiments, each done in quadruplicate. 
cells through the range of applied concentrations and the $\mathrm{IC}_{50}$ values are presented in Fig. 7. The new $\mathrm{Rh}^{\mathrm{III}}$ complexes (1) and (2), in contrast to the reference compounds, showed selectivity between tumor cell lines and non-tumor MRC-5 cells (Table 7). Cell lines HT-29 and A549 were moderately sensitive to compound (2). The aqua complex (1) was 8-fold more active against the HT-29 than A549 cell lines. The human colon adenocarcinoma cells HT-29 were found very sensitive to (1). Only HeLa cells were sensitive to all complexes, while the breast carcinoma cell line MCF-7 was only sensitive to doxorubicin. None of the tested compounds inhibited cell growth of normal fetal fibroblasts (MRC-5) to more than $50 \%$ after $48 \mathrm{~h}$ of treatment within the applied range of concentrations (Fig. 7). The ligand exchange kinetics for rhodium is rather slow but we are not sure that what we observe in the proliferation inhibition experiments is not a kinetic effect originated from the conversion of (2) into (1); this means that the activity of both compounds may arise due to aqua complex (1) only. Doxorubicin and cisplatin were consistently and non-specifically cytotoxic to all treated cell lines.

Exposure of phosphatidylserine at the outer surface of cell membrane is one of the first events when a cell is committed to apoptosis. Due to the fact that Annexin V (a calcium-dependent phospholipid-binding protein) shows affinity to bind to the cell membrane, this molecule was used for detecting apoptotic cells. $^{38}$ 7-AAD, a fluorescent dye with high affinity for DNA, was employed for distinguishing between viable and late apoptotic or necrotic cells, since this large molecule cannot pass through an intact cell membrane. Therefore, flow cytometry of Annexin

Table 7 Cytostatic activity of complexes (1) and (2) and ed3a ${ }^{3-}$ ligand against tumor strains

\begin{tabular}{lllllr}
\hline & \multicolumn{1}{c}{$\mathrm{IC}_{50}, \mu \mathrm{M}$} & & & & \\
\cline { 2 - 6 } Compound & MRC-5 & MCF-7 & A549 & HT-29 & HeLa \\
\hline$(1)$ & $>100$ & $>100$ & 16.83 & 1.96 & 1.10 \\
$(2)$ & $>100$ & $>100$ & 24.28 & 37.64 & 20.54 \\
$\mathrm{Na}_{2}$ Hed3a & $>100$ & $>100$ & 18.01 & $>100$ & 13.86 \\
Doxorubicin & 0.12 & 0.75 & 7.86 & 0.32 & 1.17 \\
Cisplatin & 0.45 & 1.5 & 36.12 & 22.05 & 2.02
\end{tabular}

V-FITC/7-AAD stained cells is considered as golden standard for detecting apoptosis. Our results show that (1) and (2) induce apoptosis in HeLa cells (Fig. 8). The majority of cells were early apoptotic (39.38\% and $28.71 \%$, respectively), a small percentage of cells were in late apoptosis (2.1\% and $1.88 \%$, respectively), while minor a percentage of cells were necrotic $(0.17 ; 0.19)$.

Although exposure of PS on the outer leaflet of the cell membrane is considered as hallmark of apoptosis, translocation of PS can occur in other types of cell death. ${ }^{39}$ Therefore, more than one method has to be utilized to verify apoptosis. Cell morphology assessment may be the most reliable method for discrimination of apoptosis. ${ }^{40}$ When the apoptotic program is started, cells shrink and become rounded, chromatin is

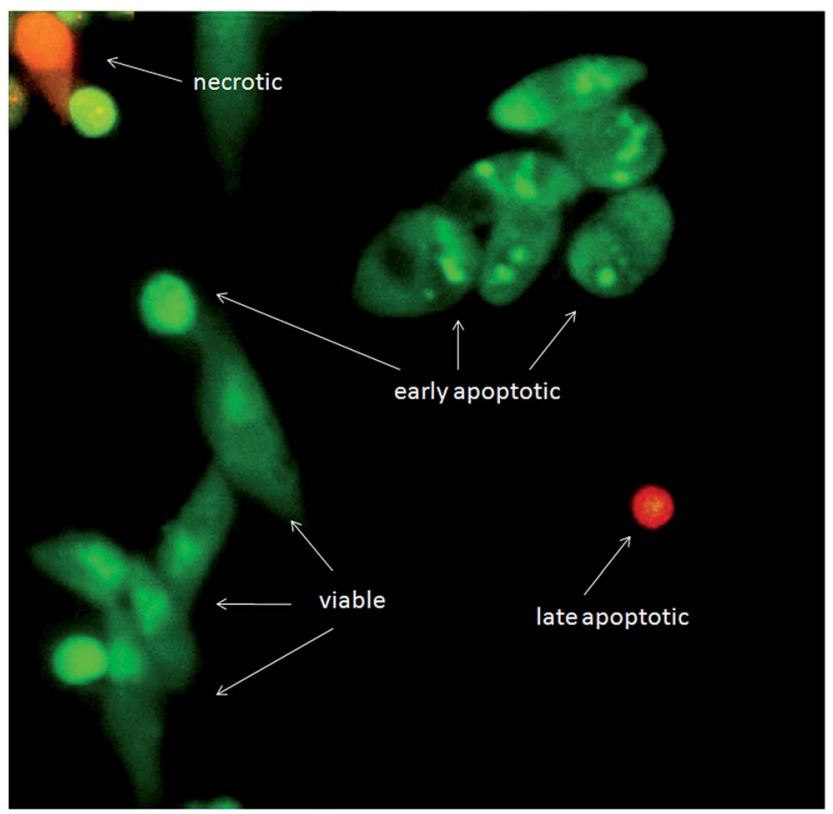

Fig. 9 Changes in morphology of HeLa cells after treatment visualized by $A O / E B$ staining. Both (1) and (2) induced alterations typical for apoptosis. Nuclei of viable cells are green with organized structure, whereas nuclei of early apoptotic cells are bright green and of late apoptotic cells bright orange to red with condensed chromatin. Necrotic cells have normal morphology and orange to red nuclei with organized structure.
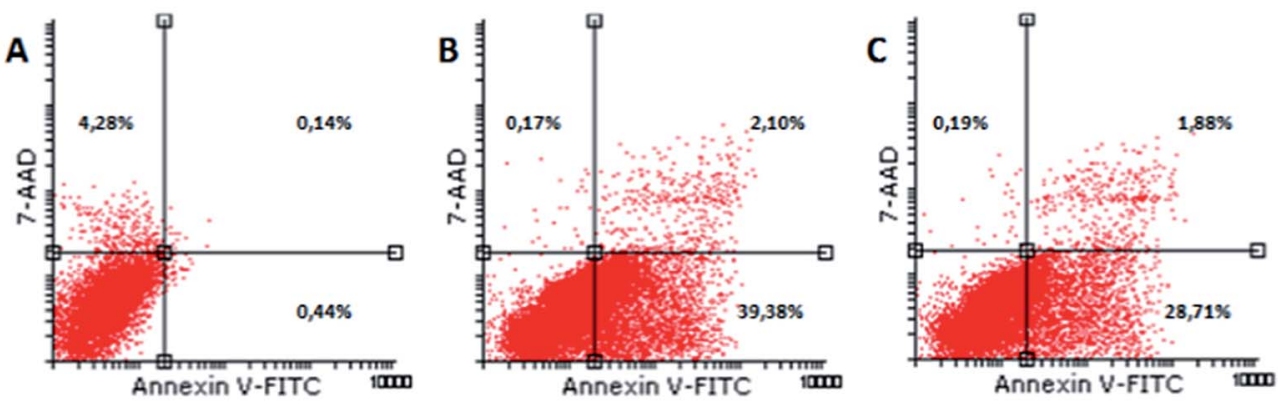

Fig. 8 Flow cytometric analysis of Annexin $V$-FITC/7-AAD staining. Dot plots present percentages of viable (Annexin $\left.V^{-} 7-A^{-} D^{-}\right)$, early apoptotic $\left(A n n e x i n V^{+} 7-A A D^{-}\right.$), late apoptotic (Annexin $V^{+} 7-A A D^{+}$) and necrotic cells (Annexin $\mathrm{V}^{-} 7-\mathrm{AAD}^{+}$) in untreated HeLa cells (A) and cells treated with $\mathrm{IC}_{50}$ concentration of (1) (B) and (2) (C). 


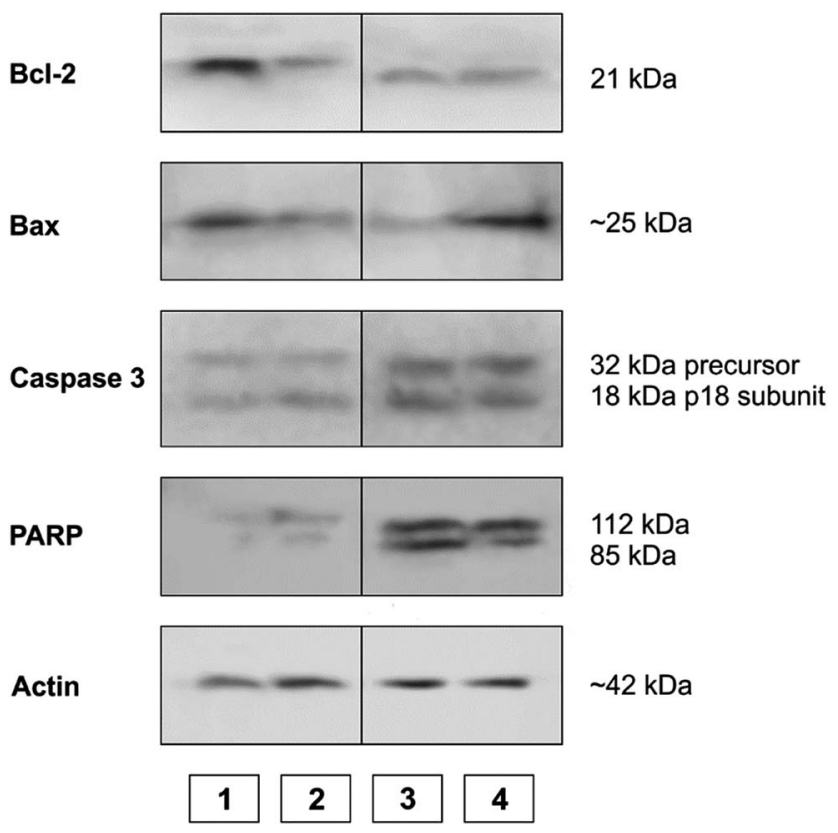

Fig. 10 The expression of apoptotic proteins investigated by Western blot analysis. (1) Control sample; (2) doxorubicin; (3) $\mathrm{Na}[\mathrm{Rh}($ ed3a)Cl]. $\mathrm{H}_{2} \mathrm{O}$ (2); (4) $\left[\mathrm{Rh}(\mathrm{ed} 3 \mathrm{a})\left(\mathrm{OH}_{2}\right)\right] \cdot \mathrm{H}_{2} \mathrm{O}$ (1). condensing and fragmenting. Using AO/EB staining, we confirmed that cells treated with the tested substances show all morphological changes typical for apoptosis (Fig. 9). AO/EB staining enabled discrimination between viable, early apoptotic, late apoptotic and necrotic cells after $24 \mathrm{~h}$ treatment with the tested substances.

WB analysis of the effects of the tested compounds (Fig. 9 and 10) indicates that, in comparison with the control, they decrease the amount of the Bcl-2 protein, similar to doxorubicin; Bax protein expression is only increased with $\left[\mathrm{Rh}(\mathrm{ed} 3 \mathrm{a})\left(\mathrm{OH}_{2}\right)\right] \cdot \mathrm{H}_{2} \mathrm{O}$ (1). Both $\mathrm{Rh}^{\mathrm{III}}$ complexes increase the expression of caspase 3 (Fig. 10 and 11), which indicates the involvement of caspase 3 in apoptotic processes of the investigated cell line. WB also demonstrate proteolytic cleavage of poly-(ADP-ribose)polymerase (PARP) in HeLa cells, after treatment with both (1) and (2) (Fig. 9 and 10). Actin was used as an internal control and shows uniform expression in all samples. The variations were within a range of $\pm 5 \%$, compared to the control.

The expression pattern of the investigated proteins of the apoptotic signaling pathway of the most affected tumor cell line HeLa reveals a conducted apoptosis. This is confirmed by the detection of PARP protein cleavage in samples treated with both $\mathrm{Rh}^{\mathrm{III}}$ complexes (1) and (2). The reduction of Bcl-2 protein
$\mathrm{Bcl}-2$

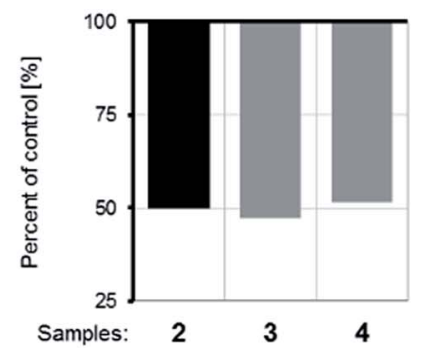

Caspase 3

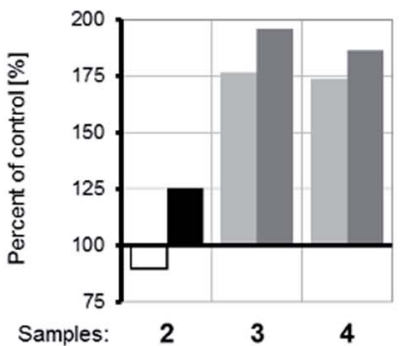

Bax

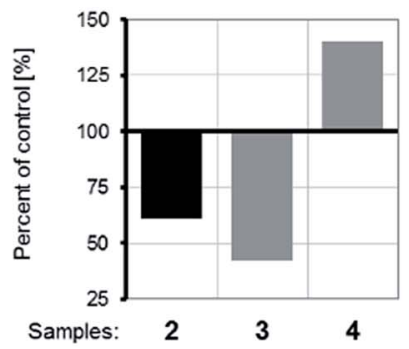

PARP

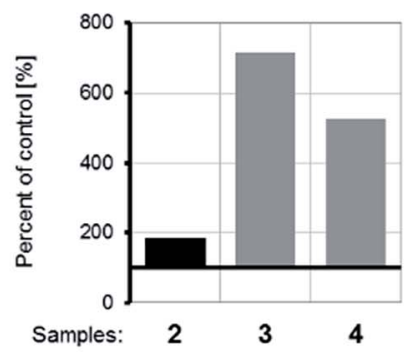

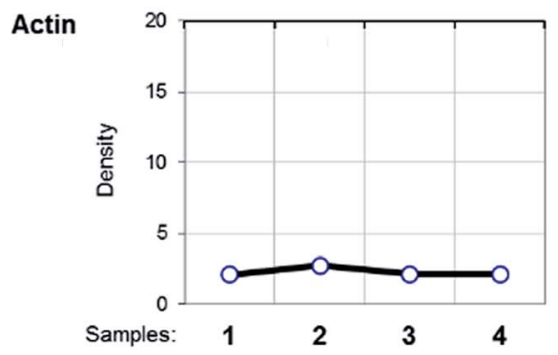

Fig. 11 Graphical presentation of protein expression densitometry data obtained by WB analysis and processed with ImageJ [http:// imagej.nih.gov]. Expression of proteins belonging to an apoptotic signaling pathway in the samples are compared to untreated samples and presented as percentage of control. The densitometry of actin expression, which serves as internal control, is presented as measured. (1) Control; (2) doxorubicin; (3) $\mathrm{Na}[\mathrm{Rh}(\mathrm{ed} 3 \mathrm{a}) \mathrm{Cl}] \cdot \mathrm{H}_{2} \mathrm{O}$ (2); (4) $\left[\mathrm{Rh}(\mathrm{ed} 3 \mathrm{a})\left(\mathrm{OH}_{2}\right)\right] \cdot \mathrm{H}_{2} \mathrm{O}$ (1). 


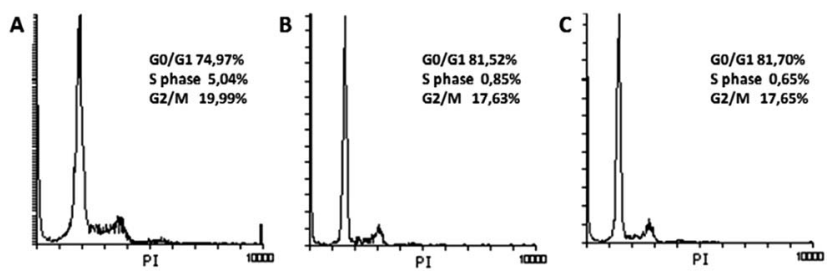

Fig. 12 Cell cycle analysis. Histograms present cell cycle distribution in untreated HeLa cells (A) and cells treated for $48 \mathrm{~h}$ with (1) (B) and (2) (C).

expression after the treatment was observed in samples. Also, a much larger increase of Bax protein expression relative to the control was observed after treatment with $\left[\mathrm{Rh}(\mathrm{ed} 3 \mathrm{a})\left(\mathrm{OH}_{2}\right)\right] \cdot \mathrm{H}_{2} \mathrm{O}$ (1) (sample 4). Bcl-2 and Bax proteins are important members of the $\mathrm{Bcl}$ protein family and are located at the beginning of the apoptotic signaling pathway. ${ }^{\mathbf{4 1 , 4 2}}$

Factors that can influence their balance may instigate cells to survival or death. Antiapoptotic Bcl-2 proteins block the intrinsic apoptosis pathway. Their concentration is increased in human cancer cells and they are important targets for new therapies. $^{\mathbf{4 1 , 4 2}}$ Therefore, the observed decrease (down regulated) $\mathrm{Bcl}-2$ expression as a result of the two new $\mathrm{Rh}^{\mathrm{III}}$ complexes (1) and (2), as well as the upregulation of Bax expression by complex (1) are of pharmacological importance.

Protein expression analysis also gives a picture of increased caspase 3 activity, which suggests that the caspase-dependent apoptosis underlies the observed cytotoxic effect.

Both cell cycle progression and apoptosis are crucial for maintaining tissue homeostasis. These sets of events are coupled and share certain regulatory molecules. Cellular damage and stress signals result in cell cycle termination that provide the cell a time to repair the damage. If the cell cannot recover, the apoptotic program is activated. Analysis of the cell cycle in HeLa cells treated with (1) and (2) (Fig. 12) showed that both substances induced G0/G1 cycle termination (from $74.97 \%$ in untreated cells to $81.70 \%$ in cells treated with complex (1) and $81.52 \%$ when treated with complex (2)). Concomitantly, the percentage of cells in the S phase decreased from $5.04 \%$ in control cells to $0.65 \%$ and $0.85 \%$, respectively. These results indicate that blockade of DNA synthesis induced by the tested substances is a possible trigger of apoptosis.

\section{Conclusions}

Two new $\mathrm{Rh}^{\mathrm{III}}$-ed $3 \mathrm{a}^{3-}$ complexes, the neutral cis-equatorial$\left[\mathrm{Rh}(\mathrm{ed} 3 \mathrm{a})\left(\mathrm{OH}_{2}\right)\right] \cdot \mathrm{H}_{2} \mathrm{O}$ (1) and the anionic cis-equatorial-Na $[\mathrm{Rh}($ ed $3 \mathrm{a}) \mathrm{Cl}] \cdot \mathrm{H}_{2} \mathrm{O}(2)$, were isolated and characterized using experimental and computational techniques. The cis-equatorial geometry was verified by X-ray crystallography for (1) and (2) and solution spectroscopy (UV-Vis, IR, NMR) indicates that, for (1) this is retained in solution and that it is also the geometry of (2), as expected from published strain energy analyses of similar systems. ${ }^{5} \mathrm{MM}$ and DFT results are in agreement with the experimental X-ray and spectroscopic data and the observed isomer preference. The composition and conditional stability constants of $\mathrm{Rh}^{\mathrm{III}}$ complexes were determined by $\mathrm{pH}$ potentiometry and UV-Vis spectrophotometry. The speciation scheme of the $\mathrm{Rh}^{\mathrm{III}}$-ed $3 \mathrm{a}^{3-}$ system consists of four species: $[\mathrm{Rh}(\mathrm{Hed} 3 \mathrm{a})]^{+},[\mathrm{Rh}(\mathrm{ed} 3 \mathrm{a})],\left[\mathrm{Rh}(\mathrm{ed} 3 \mathrm{a})_{2}\right]^{3-}$ and $[\mathrm{Rh}(\mathrm{OH})(\mathrm{ed} 3 \mathrm{a})]^{-}$. At physiological $\mathrm{pH}$ the dominant species in the system are $[\mathrm{Rh}(\mathrm{Hed} 3 \mathrm{a})]^{+}$and $[\mathrm{Rh}(\mathrm{ed} 3 \mathrm{a})]$ complexes. Knowledge of the composition and stability of these complexes in the system can contribute to a better understanding of their physiological roles in different tissues and cell system. Biological tests demonstrated that the $\mathrm{Rh}^{\mathrm{III}}$ complexes (1) and (2) show an interesting cytotoxicity behaviour in comparison to the doxorubicin and cisplatin reference systems: in contrast to these, they are inactive against the MCF-7 human breast carcinoma and healthy MRC-5 cell lines but are very active against the human cervix adenocarcinoma HeLa cell line. Against HT-29 and A549 cells, the aqua complex (1) is significantly more active than the chloro complex (2). Flow cytometry and Western blot analysis revealed mechanism of antitumor activity of tested complexes: cytostatic as a result of DNA synthesis blockade and cytotoxic through induction of apoptosis.

\section{Experimental}

\section{Materials and methods}

Reagent grade commercially available chemicals were used without further purification. The preparation of the calcium salt of ed $3 \mathrm{a}^{3-}, \mathrm{Ca}_{3}(\mathrm{ed} 3 \mathrm{a})_{2} \cdot 12 \mathrm{H}_{2} \mathrm{O}$ was reported previously. ${ }^{5}$ Monochloroacetic acid, ethylenediamine, calcium hydroxide, $\mathrm{Rh}^{\mathrm{III}}$ chloride hydrate, hydrochloric acid, sodium hydroxide and sodium chloride were purchased from Sigma-Aldrich. A rhodium(III) chloride stock solution was prepared by dissolving dried $\mathrm{RhCl}_{3} \cdot \mathrm{H}_{2} \mathrm{O}$, p.a. (Sigma-Aldrich), in doubly-distilled water. Elemental microanalyses for $\mathrm{C}, \mathrm{H}, \mathrm{N}$ were performed on a CHN-O-vario EL by the Microanalysis Laboratory at the chemical institutes at Heidelberg University. IR spectra were measured with a Perkin-Elmer 16 PC FTIR instrument as $\mathrm{KBr}$ pellets. NMR spectra were recorded at $200 \mathrm{MHz}\left({ }^{1} \mathrm{H}\right)$ and 50 $\mathrm{MHz}\left({ }^{13} \mathrm{C}\right)$ on a Bruker Advance I 200 instrument with deuterated solvents as reference. Electronic absorption spectra were obtained from a Tidas II J\&M spectrophotometer at concentrations of the $\mathrm{Rh}^{\mathrm{III}}$ complexes (aqueous solutions) of approx. $1.0 \times$ $10^{-3} \mathrm{M}$. The potentiometric measurements were carried out using a Methrom $827 \mathrm{pH}$ meter with a Titronic universal piston burette and combined glass electrode. Spectroscopic measurements were made with a double beam UV-Vis spectrophotometer model Cary 300 (Agilent Technologies, Santa Clara, USA) with $1.0 \mathrm{~cm}$ quartz cells. Melting points were determined using a Stuart digital melting point apparatus with accuracy $\pm 1{ }^{\circ} \mathrm{C}$.

\section{Synthetic procedures}

Preparation of cis-eq- $\left[\mathbf{R h}(\mathbf{e d} 3 \mathbf{a})\left(\mathrm{OH}_{2}\right)\right] \cdot \mathbf{H}_{2} \mathbf{O}(\mathbf{1}) \cdot \mathrm{Ca}_{3}(\mathrm{ed} 3 \mathrm{a})_{2^{-}}$ $\cdot 12 \mathrm{H}_{2} \mathrm{O}$ (1.99 g; $2.5 \mathrm{mmol}$ ) was dissolved in water $(15 \mathrm{~mL})$ and solution of $\mathrm{NaOH}(0.6 \mathrm{~g}, 15 \mathrm{mmol})$ in water $(5 \mathrm{~mL})$ was added. The deposited $\mathrm{Ca}(\mathrm{OH})_{2}$ was separated by filtration; to the filtrate was added a solution of $\mathrm{RhCl}_{3} \cdot \mathrm{H}_{2} \mathrm{O}(1.14 \mathrm{~g}, 5 \mathrm{mmol})$ in water (5 $\mathrm{mL}$ ). The resulting mixture was stirred at $145{ }^{\circ} \mathrm{C}$ for $7 \mathrm{~h}$ in a closed Pyrex tube. After cooling to room temperature the yellow solution was filtered off and the filtrate was passed 
through a column of QAE A-25 Sephadex in the $\mathrm{Cl}^{-}$form. The column was eluted with $100 \mathrm{mM} \mathrm{NaCl}$. Three yellow bands with different charges appeared; the first band was evaporated and desalted by passage through a Sephadex G-10 column with distilled water as eluent. The eluate was evaporated to $c a .1 \mathrm{~mL}$ and neutral cis-equatorial-[Rh(ed3a) $\left.\left(\mathrm{OH}_{2}\right)\right] \cdot \mathrm{H}_{2} \mathrm{O}$ complex was crystallized after adding ethanol and cooling the solution in a refrigerator. The yellow crystals were collected, washed with ethanol and air-dried. Yield: $0.4 \mathrm{~g}, 21.69 \%$. Melting point: $>305{ }^{\circ} \mathrm{C}$ (from EtOH). Anal. calc. for $\mathrm{C}_{8} \mathrm{H}_{15} \mathrm{~N}_{2} \mathrm{O}_{8} \mathrm{Rh}(\mathrm{FW}=$ $370.13 \mathrm{~g} \mathrm{~mol}^{-1}$ ): C, 25.96; H, 4.08; N, 7.57\%. Found: C, 25.37; H, 4.22; N, 7.36\%. IR (KBr, $\left.\nu_{\max } \mathrm{cm}^{-1}\right): 1631 \nu\left(\mathrm{COO}^{-}\right), 3435 \nu(\mathrm{N}-\mathrm{H})$. UV-Vis $\lambda_{\max }\left(\mathrm{H}_{2} \mathrm{O}\right) / \mathrm{nm}\left(\varepsilon / \mathrm{dm}^{3} \mathrm{~mol}^{-1} \mathrm{~cm}^{-1}\right): 294$ (326.51) and 353 (405.59). $\delta{ }^{1} \mathrm{H}$ NMR (200 MHz, $\mathrm{D}_{2} \mathrm{O}, \mathrm{Me}_{4} \mathrm{Si}$ ): 4.09 (AB pattern, $\mathrm{G}$ ring), 4.05 ( $\mathrm{s}, \mathrm{R}_{1}$ ring), 3.30 ( $\mathrm{AB}$ pattern, $\mathrm{R}_{2}$ ring); $\delta{ }^{13} \mathrm{C} \mathrm{NMR}(50$ $\left.\mathrm{MHz}, \mathrm{D}_{2} \mathrm{O} / \mathrm{CD}_{3} \mathrm{OD}, \mathrm{Me}_{4} \mathrm{Si}\right): 184.26,182.84,181.26(\mathrm{C}=\mathrm{O}), 67.30$, 64.59, 62.70, 56.53, $56.17\left(\mathrm{CH}_{2}\right)$.

Preparation of cis-eq- $\mathrm{Na}[\mathrm{Rh}(\mathrm{ed} 3 \mathrm{a}) \mathrm{Cl}] \cdot \mathrm{H}_{2} \mathrm{O}$ (2). For the preparation of $\mathrm{Na}[\mathrm{Rh}(\mathrm{ed} 3 \mathrm{a}) \mathrm{Cl}] \cdot \mathrm{H}_{2} \mathrm{O}$, the same procedure as for (1) was used. The second band was evaporated and desalted over a Sephadex G-10 column with distilled water as eluent. The eluate was evaporated to $c a .3 \mathrm{~mL}$ and left to crystallize from ethanol overnight in a refrigerator. The yellow crystals of cisequatorial- $\mathrm{Na}[\mathrm{Rh}(\mathrm{ed} 3 \mathrm{a}) \mathrm{Cl}] \cdot \mathrm{H}_{2} \mathrm{O}$ were collected, washed with ethanol and air-dried. Yield: $0.800 \mathrm{~g}, 39.10 \%$. Melting point: $>305{ }^{\circ} \mathrm{C}$ (from EtOH). Anal. calc. for $\mathrm{C}_{8} \mathrm{H}_{13} \mathrm{ClN}_{2} \mathrm{NaO}_{7} \mathrm{Rh}(\mathrm{FW}=$ $410.55 \mathrm{~g} \mathrm{~mol}^{-1}$ ): C, 23.40; H, 3.19; N, 6.82\%. Found: C, 23.55; H, 3.39; N, 6.99\%. IR (KBr, $\left.\nu_{\max } \mathrm{cm}^{-1}\right): 1630$ and $1680 \nu\left(\mathrm{COO}^{-}\right)$, $3426 \nu(\mathrm{N}-\mathrm{H})$. UV-Vis $\lambda_{\max }\left(\mathrm{H}_{2} \mathrm{O}\right) / \mathrm{nm}\left(\varepsilon / \mathrm{dm}^{3} \mathrm{~mol}^{-1} \mathrm{~cm}^{-1}\right): 307$
(447.77) and 373 (512.13). $\delta{ }^{1} \mathrm{H}$ NMR (200 MHz, $\mathrm{D}_{2} \mathrm{O}, \mathrm{Me}_{4} \mathrm{Si}$ ): 4.05 (AB pattern, $\mathrm{G}$ ring), 3.99 (s, $\mathrm{R}_{1}$ ring), 3.34 (AB pattern, $\mathrm{R}_{2}$ ring) $\delta{ }^{13} \mathrm{C} \mathrm{NMR}\left(50 \mathrm{MHz}, \mathrm{D}_{2} \mathrm{O} / \mathrm{CD}_{3} \mathrm{OD}, \mathrm{Me}_{4} \mathrm{Si}\right.$ ): 184.67, 183.71, $182.10(\mathrm{C}=\mathrm{O}), 66.60,63.72,61.84,57.37,57.04\left(\mathrm{CH}_{2}\right)$. The third band, remaining on top of the column after elution with $100 \mathrm{mM} \mathrm{NaCl}$, was eluted with concentrated $\mathrm{NaCl}$ and was found to be a mixture of different hydroxo species with charges higher than -2 .

\section{Crystal structure determination}

Crystal data and details of the structure determinations are listed in Table 8. Full shells of intensity data were collected at low temperature with an Agilent Technologies Supernova-E CCD diffractometer (Mo-K $\alpha$ radiation for complex (1) and $\mathrm{Cu}-$ $\mathrm{K} \alpha$ radiation for complex (2), microfocus tubes, multilayer mirror optics). Data were corrected for air and detector absorption, Lorentz and polarization effects; ${ }^{43}$ absorption by the crystal was treated numerically (Gaussian grid). ${ }^{\mathbf{4 3 4}}$ The structures were solved by intrinsic phasing ${ }^{45}$ (complex (1)) or by the heavy-atom method combined with structure expansion by direct methods applied to difference structure factors ${ }^{\mathbf{4 6}}$ (complex (2)) and refined by full-matrix least squares methods based on $F^{2}$ against all unique reflections. ${ }^{47}$ All non-hydrogen atoms were given anisotropic displacement parameters. Hydrogen atoms were generally input at calculated positions and refined with a riding model.

The positions of some hydrogen atoms (those on $\mathrm{N}$ and $\mathrm{O}$ ) were taken from difference Fourier syntheses and refined.

Table 8 Details of the crystal structure determinations of $\left[\mathrm{Rh}(\mathrm{ed} 3 \mathrm{a})\left(\mathrm{OH}_{2}\right)\right] \cdot \mathrm{H}_{2} \mathrm{O}(1)$ and $\mathrm{Na}[\mathrm{Rh}(\mathrm{ed} 3 \mathrm{a}) \mathrm{Cl}] \cdot \mathrm{H}_{2} \mathrm{O}$ (2)

\begin{tabular}{|c|c|c|}
\hline & (1) & $(2)$ \\
\hline Formula & $\mathrm{C}_{8} \mathrm{H}_{15} \mathrm{~N}_{2} \mathrm{O}_{8} \mathrm{Rh}$ & $\mathrm{C}_{8} \mathrm{H}_{13} \mathrm{ClN}_{2} \mathrm{NaO}_{7} \mathrm{Rh}$ \\
\hline$M_{\mathrm{r}}$ & 370.13 & 410.55 \\
\hline Crystal system & Monoclinic & Monoclinic \\
\hline Space group & $P 2_{1} / n$ & $P 2_{1} / c$ \\
\hline$a / \AA$ & $6.94313(8)$ & $13.4003(6)$ \\
\hline$b / \AA$ & $15.71268(18)$ & $6.9326(3)$ \\
\hline$c / \AA$ & $11.09315(11)$ & $14.9772(8)$ \\
\hline$\beta /^{\circ}$ & $96.9886(10)$ & $115.328(6)$ \\
\hline$V / \AA^{3}$ & $1201.22(2)$ & $1257.62(12)$ \\
\hline$Z$ & 4 & 4 \\
\hline$F_{000}$ & 744 & 816 \\
\hline$d_{\mathrm{c}} / \mathrm{Mg} \mathrm{m}^{-3}$ & 2.047 & 2.168 \\
\hline $\mathrm{X}$-radiation, $\lambda / \AA$ & Мo-K $\alpha, 0.71073$ & $\mathrm{Cu}-\mathrm{K} \alpha, 1.5418$ \\
\hline$\mu / \mathrm{mm}^{-1}$ & 1.462 & 13.639 \\
\hline Max., min. transmission factors & $0.946,0.792$ & $0.815,0.285$ \\
\hline Data collect. temp./K & $110(1)$ & $110(1)$ \\
\hline$\theta$ range $/^{\circ}$ & 3.2 to 29.0 & 3.7 to 70.9 \\
\hline Index ranges (indep. set) $h, k, l$ & $-9 \ldots 9,-21 \ldots 21,-15 \ldots 15$ & $-16 \ldots 16,-8 \ldots 8,-17 \ldots 15$ \\
\hline Reflections measured & 66435 & 24110 \\
\hline Unique $\left[R_{\text {int }}\right]$ & $3126[0.0598]$ & $2410[0.0938]$ \\
\hline Observed $[I \geq 2 \sigma(I)]$ & 2965 & 1861 \\
\hline Data/restraints/parameters & $3126 / 0 / 87$ & $2410 / 0 / 190$ \\
\hline GooF on $F^{2}$ & 1.276 & 1.030 \\
\hline$R$ indices $[F>4 \sigma(F)] R(F), \mathrm{w} R\left(F^{2}\right)$ & $0.0313,0.0518$ & $0.0332,0.0739$ \\
\hline$R$ indices (all data) $R(F), \mathrm{w} R\left(F^{2}\right)$ & $0.0358,0.0527$ & $0.0510,0.0807$ \\
\hline Difference density: $\max , \min / \mathrm{e}^{-3}$ & $0.520,-0.671$ & $1.334,-0.647$ \\
\hline
\end{tabular}


CCDC 1412103 (for (1)), CCDC 1412104 (for (2)) contain the supplementary crystallographic data for this paper. $\dagger$

\section{Solution studies}

All the equilibrium measurements were made at a constant ionic strength maintained by $0.1 \mathrm{M} \mathrm{NaCl}$ at $25{ }^{\circ} \mathrm{C}$. To determine the protonation constants of ed $3 \mathrm{a}^{3-}$ and conditional stability constants of the complexes formed with ed $3 \mathrm{a}^{3-}$ were determined by potentiometric titrations. The metal-to-ligand ratios were $1: 1.5$ and $1: 3$. The concentration of the $\mathrm{Rh}^{\mathrm{III}}$ was $2 \mathrm{mM}$.

The potentiometric measurements were carried out using a Methrom $827 \mathrm{pH}$ meter with a Titronic universal Piston burette and combined glass electrode. The temperature of the sample solutions $(20 \mathrm{~mL})$ was maintained at $25.0{ }^{\circ} \mathrm{C}$ by circulating thermostatically controlled water through the jacket of the titration vessel. The samples were stirred with a magnetic stirrer, and to avoid the effect of $\mathrm{CO}_{2}$. All of the measurements were performed under a nitrogen atmosphere.

Spectroscopic measurements were made on solutions in which the concentration of $\mathrm{Rh}^{\mathrm{III}}$ and ed $3 \mathrm{a}^{3-}$ were constant $\left(C_{\mathrm{Rh}}\right.$ $=2.0 \mathrm{mM}, C_{\text {ed } 3 \mathrm{a}}=6.2 \mathrm{mM}$ and $C_{\text {ed } 3 \mathrm{a}}=3.1 \mathrm{mM}$ ), while the $\mathrm{pH}$ was varied between 2.5 and 7.8. The $\mathrm{pH}$ of the test solutions was measured with a Methrom $827 \mathrm{pH}$ meter. Stable values within $0.02 \mathrm{pH}$ and 0.01 absorbance units, were attained for the first series of solutions after $1 \mathrm{~h}$ at $25{ }^{\circ} \mathrm{C}$ (these remained stable for $30 \mathrm{~min}$ ), and for the second series after heating for $3 \mathrm{~h}$ at $145^{\circ} \mathrm{C}$ (closed vessel, see above), and these remained stable for $3 \mathrm{~h}$ at the same temperature. Spectra of the test solutions were recorded in the $250-600 \mathrm{~nm}$ wavelength range. To calculate the equilibrium constants the HYPERQUAD2006 and HypSpec2014 programs were used. ${ }^{27,29}$ The concentration distribution diagrams were obtained using the program HYSS2006 under the experimental conditions described. ${ }^{48}$

\section{Computational details}

DFT calculations. Geometries for $\mathrm{Rh}^{\mathrm{III}}$ complexes were optimized using Gaussian 09 A01 program..$^{32}$ The Becke threeparameter exchange functional was employed in this study in conjunction with the Lee-Yang-Parr correlation hybrid functional (B3LYP) and the Ahlrich's def2-TZVP basis set. ${ }^{49}$ The systems were treated within the restricted formalism. All the calculations were done under the Polarizable Continuum Model (PCM) with the solute being water as implemented in G09 package. All the calculated structures were verified to be local minima (all positive eigenvalues by frequency analysis) for ground state structures. Starting geometries were taken either from experimental X-ray structures or were pre-optimized using the molecular mechanics.

Molecular mechanics (force field) calculation. Molecular mechanics calculations were performed using the strain energy minimization program MOMEC..$^{33}$ Within the framework of the molecular mechanics, the structure of a molecule was modified to minimize its total strain energy. Strain energy includes: bond lengths deformation $\left(E_{\mathrm{b}}\right)$, valence angle deformation $\left(E_{\theta}\right)$, torsion angle deformation $\left(E_{\Phi}\right)$, nonbonded interactions $\left(E_{\mathrm{nb}}\right)$ and out-of-plane deformation $\left(E_{\delta}\right)($ eqn $(4))$ :

$$
U_{\text {total }}=\sum\left(E_{\mathrm{b}}+E_{\theta}+E_{\Phi}+E_{\mathrm{nb}}+E_{\delta}\right)
$$

Input coordinates were obtained from crystal structures data or produced with HyperChem 7.01. ${ }^{50}$ Parameters not reported before are given in Table 9. All other parameters are given in the literature. ${ }^{34}$

\section{Biological tests}

Cell lines. All human solid tumor and normal cell lines were purchased from American Type Culture Collection-ATCC. The cell lines used in the study were A549 (human lung carcinoma, ATCC CCL 185), MCF-7 (human breast adenocarcinoma, ATCC HTB22), HT-29 (human colon adenocarcinoma, ATCC HTB38), HeLa (human cervix adenocarcinoma, ATCC CCL2) and MRC-5 (normal human fetal lung fibroblasts, ATCC CCL 171). The cells were grown in Dulbecco's modified Eagle's medium (DMEM, Sigma) with $4.5 \%$ of glucose, supplemented with $10 \%$ of fetal bovine serum (FBS, Sigma) and antibiotics and antimicotics solution (Sigma). All cell lines were cultured at $37{ }^{\circ} \mathrm{C}$ in the $100 \%$ humidity atmosphere and $5 \%$ of $\mathrm{CO}_{2}$. Exponentially growing cells were used throughout the assays.

MTT assay. Growth inhibition was evaluated by tetrazolium colorimetric MTT assay (SIGMA). ${ }^{51}$ Exponentially growing cells

Table 9 New force field parameters for Rh-edta type of complexes ${ }^{a}$

Bond distance parameters

\begin{tabular}{lll}
\hline Bond type & $\begin{array}{l}\text { Force constant } \\
\left(\text { mdyn } \AA^{-1}\right)\end{array}$ & $\begin{array}{l}\text { Strain-free bond } \\
\text { distance }(\AA)\end{array}$ \\
\hline $\mathrm{Rh}-\mathrm{N}_{\text {diamine }}$ & 1.75 & 2.05 \\
$\mathrm{Rh}-\mathrm{Cl}$ & 1 & 2.35 \\
$\mathrm{Rh}-\mathrm{O}_{\text {carboxyl }}$ & 1.75 & 1.99 \\
$\mathrm{Rh}-\mathrm{O}_{\text {water }}$ & 0.5 & 1.9 \\
\hline
\end{tabular}

Valence angle parameters

\begin{tabular}{|c|c|c|}
\hline Valence angle type & 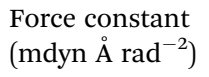 & $\begin{array}{l}\text { Strain-free valence } \\
\text { angle (rad) }\end{array}$ \\
\hline $\mathrm{O}_{\text {carboxyl }}-\mathrm{Rh}-\mathrm{O}_{\text {carboxyl }}$ & 0.026 & 1.571 \\
\hline $\mathrm{Cl}-\mathrm{Rh}-\mathrm{O}_{\text {carboxyl }}$ & 0.026 & 1.571 \\
\hline $\mathrm{O}_{\text {carboxyl }}-\mathrm{Rh}-\mathrm{N}_{\text {diamine }}$ & 0.026 & 1.571 \\
\hline $\mathrm{O}_{\text {carboxyl }}-\mathrm{Rh}-\mathrm{O}_{\text {water }}$ & 0.026 & 1.571 \\
\hline Cl-Rh-N(diamine) & 0.026 & 1.571 \\
\hline $\mathrm{N}_{\text {diamine }}-\mathrm{Rh}-\mathrm{N}_{\text {diamine }}$ & 0.026 & 1.571 \\
\hline $\mathrm{N}_{\text {diamine }}-\mathrm{Rh}-\mathrm{O}_{\text {water }}$ & 0.026 & 1.571 \\
\hline $\mathrm{Rh}-\mathrm{O}_{\text {water }}-\mathrm{H}$ & 0.100 & 1.915 \\
\hline $\mathrm{Rh}-\mathrm{O}_{\text {carboxyl }}-\mathrm{C}_{\text {carboxyl }}$ & 0.026 & 1.970 \\
\hline
\end{tabular}

Torsion angle parameters

\begin{tabular}{lll}
\hline Bond torsion angle type & $\begin{array}{l}\text { Force constant } \\
\text { (mdyn } \AA \text { ) }\end{array}$ & $\begin{array}{l}\text { Offset angle } \\
\text { (rad) }\end{array}$ \\
\hline $\mathrm{O}_{\text {carboxyl }}-\mathrm{Rh}$ & 0.0000 & 0.0000 \\
$\mathrm{~N}_{\text {diamine }}-\mathrm{Rh}$ & 0.0000 & 0.0000 \\
$\mathrm{O}_{\text {water }}-\mathrm{Rh}$ & 0.0000 & 0.0000 \\
$\mathrm{Rh}-\mathrm{O}_{\text {carboxyl }}-\mathrm{C}_{\text {carboxyl }}-\mathrm{O}_{\text {carboxyl }}$ & 0.0400 & 0.0570
\end{tabular}

$\mathrm{Rh}-\mathrm{O}_{\text {carboxyl }}-\mathrm{C}_{\text {carboxyl }}-\mathrm{O}_{\text {carboxyl }} \quad 0.0400$

${ }^{a}$ dyn $=10^{-5} \mathrm{~N}$. 
were harvested and plated into 96-well microtiter plates (Costar) at optimal seeding density of $10 \times 10^{3}$ cells per well. Tested substances and reference compounds doxorubicin and cisplatin, at tenfold the required final concentration, were added $(10 \mu \mathrm{L}$ per well) to all wells except to the control ones and microplates were incubated for $48 \mathrm{~h}$. Three hours before the end of the incubation period, $10 \mu \mathrm{L}$ of MTT solution ( $5 \mathrm{mg} \mathrm{mL}^{-1}$ ) was added to all wells. Acid-isopropanol $(100 \mu \mathrm{L}$ of $0.04 \mathrm{~N} \mathrm{HCl}$ in isopropanol) was added to all wells and mixed thoroughly to dissolve the dark blue crystals. After a few minutes at room temperature, to ensure that all crystals were dissolved, the plates were read on a spectrophotometer plate reader (Multiscan MCC340, Labsystems) at 540/ $690 \mathrm{~nm}$. Inhibition of growth was expressed as a percent of a control and cytotoxicity was calculated according to the formula: $\left(1-A_{\text {test }} / A_{\text {control }}\right) \times 100$. The substance potency was expressed as the $\mathrm{IC}_{50}(50 \%$ inhibitory concentration). Two independent experiments were set out with quadruplicate wells for each concentration of the compound. IC $_{50}$ values were determined by Median effect analysis. ${ }^{52}$

Cell treatment for apoptosis study. The cells were seeded in 6-well plates at a concentration of $5 \times 10^{5}$ cells per well. Viability was determined using trypan blue dye-exclusion assay. Untreated cells were used as control (sample no. 1). Cells were treated with Doxorubicin as a reference compound (sample no. 2) and tested complexes (1) and (2) (sample no. 3 and 4, respectively) for $48 \mathrm{~h}$. Viable treated and control cell samples were used for apoptosis investigation by Western blot analysis.

Flow cytometric analysis. The type of cell death induced by tested substances was determined using Annexin V-FITC/7-AAD kit according to manufacturer's instructions (Beckman Coulter, USA). Briefly, HeLa cells were treated with complex (1) and complex (2) in concentrations corresponding to $\mathrm{IC}_{50}$ values or in media alone (control). After $48 \mathrm{~h}$ incubation $\left(37^{\circ} \mathrm{C}, 5 \% \mathrm{CO}_{2}\right.$ and absolute humidity) both attached and detached cells were collected, washed in PBS and finally suspended in ice cold binding buffer $\left(1 \times 10^{5}\right.$ cells per $100 \mu \mathrm{L}$ binding buffer $)$. Cells were stained with $10 \mu \mathrm{L}$ of Annexin V-FITC and $20 \mu \mathrm{L} 7-\mathrm{AAD}$ and after 15 minutes incubation in dark, $400 \mu \mathrm{L}$ of binding buffer was added to each tube. Samples were assayed by flow cytometer.

Cytomics FC500 (Beckman Coulter, USA) and the percent of viable, apoptotic and necrotic cells was evaluated using Flowing Software (http://www.flowingsoftware.com/). The results were presented by dot plots.

Cell morphology assessment. Untreated, control HeLa cells, and cells treated with complex (1) and complex (2) $\left(\mathrm{IC}_{50}\right.$ concentrations) were stained with $1 \mu \mathrm{L}$ of fluorescent dye mixture $\left(100 \mathrm{mg} \mathrm{mL}^{-1}\right.$ ethidium bromide and $100 \mathrm{mg} \mathrm{mL}$ acridine orange). Cell morphology was analyzed with fluorescence microscope (Leica DM1000, Germany) at 400× magnification. Images were taken with Canon PC 1089 camera.

Cell cycle analysis. HeLa cells were treated with (1) and (2) in concentrations corresponding to $\mathrm{IC}_{50}$ values or in media alone (control) for $48 \mathrm{~h}$ at $37{ }^{\circ} \mathrm{C}$ in an atmosphere of $5 \% \mathrm{CO}_{2}$ and absolute humidity. After incubation period cells were collected, washed in PBS and finally suspended in $1 \mathrm{~mL}$ of ice cold $70 \%$ ethanol. After overnight incubation at $+4{ }^{\circ} \mathrm{C}$ cells were washed in PBS and treated with RNase A (500 $\mu \mathrm{g} \mathrm{mL}^{-1}$ PBS) for 30 minutes at $37^{\circ} \mathrm{C} .5 \mu \mathrm{L}$ of propidium iodide $\left(10 \mathrm{mg} \mathrm{mL}^{-1} \mathrm{PBS}\right)$ was added to each tube and after 15 minutes incubation in dark samples were assayed by flow cytometer Cytomics FC500. The data were analyzed using Flowing Software and the results were presented by histograms.

Western blot. The protein concentration in cell lysate was determined by Bradford protein assay ${ }^{53}$ in a 96 well microtiter plate (ThermoLab Systems, Multiscan Accent spectrophotometer) using bovine serum albumin as the standard. Molecular mass markers for proteins were obtained from Amersham Biosciences. For the Western blot, $50 \mu \mathrm{g}$ of proteins per sample were separated by electrophoresis and electro-transferred to a polyvinylidene difluoride (PVDF) membrane Hybond-P (Amersham Biosciences, Arlington Heights, IL) and then blotted with primary antibodies (Bcl-2, PARP, caspase-3, and actin). Monoclonal antibodies against human Bcl-2 and Caspase 3 were obtained from R\&D Systems (Minneapolis, MN). Anti-poly(ADPribose)polymerase (PARP) was purchased from Santa Cruz Biotechnology (Santa Cruz, CA). Antibody against $\alpha$-, $\beta$ - or $\gamma$-actin was purchased from Sigma Chemical (St. Louis, MO). Proteins were detected by an enhanced chemiluminescence (ECL Plus) kit (Amersham Biosciences), that includes peroxidase-labeled donkey anti-rabbit and sheep anti-mouse secondary antibodies. Blots were developed with an ECL Plus detection system and recorded on Hyperfilm (Amersham Biosciences). Exposed films were processed with Kodak EX-OMAT II developer reagents and photographed on a negatoscope with Canon 1100D camera on mini-tripod. The protein expression images were analyzed by densitometry in ImageJ computer program (NIH image, http:// imagej.nih.gov) with only minor levels adjustments. Expression of apoptotic proteins in treated samples was compared to the control sample. Densitometry data processing was done in Microsoft Office Excel program.

\section{Acknowledgements}

The authors are grateful to the Serbian Ministry of Education, Science and Technological Development for the financial support (Project No. III41010). One of the authors (Marija Jeremić) is particularly grateful to the Erasmus Mundus Programme for the awarded scholarship.

\section{References}

1 (a) D. J. Radanović, Coord. Chem. Rev., 1984, 54, 159-261; (b) B. E. Douglas and D. J. Radanović, Coord. Chem. Rev., 1993, 128, 139-165.

2 (a) R. Meier, C. Platas-Iglesias, F. W. Heinemann, G. Linti, J. Schulte and S. K. Srivastava, Inorg. Chem., 2014, 53, 6684-6697; (b) A. Brausam, J. Maigut, R. Meier, P. Á. Szilágyi, H. J. Buschmann, W. Massa, Z. Homonnay and R. van Eldik, Inorg. Chem., 2009, 48, 7864-7884.

3 C. Maricondi, S. Utsuno, D. J. Radanović, S. R. Trifunović, J. E. Abola and B. Douglas, Inorg. Chim. Acta, 1988, 142, 135-149. 
4 S. Grubišić, M. Gruden-Pavlović, S. R. Niketić, S. Kaizaki and N. Sakagami-Yoshida, Inorg. Chem. Commun., 2003, 6, 11801184.

5 (a) Z. D. Matović, A. Meetsma, V. D. Miletić and P. J. van Koningsbruggen, Inorg. Chim. Acta, 2007, 360, 2420-2431; (b) S. Belošević, M. Ćendić, A. Meetsma and Z. D. Matović, Polyhedron, 2013, 50, 473-480.

6 B. Rosenberg, L. Van Camp and T. Krigas, Nature, 1965, 205, 698-699.

7 B. Rosenberg, L. Van Camp, J. E. Trosko and V. H. Mansour, Nature, 1969, 222, 385-386.

8 (a) R. B. Weiss and M. C. Christian, Drugs, 1993, 46, 360-377; (b) G. Giaccone, Drugs, 2000, 59, 9-17.

9 E. Wong and C. M. Giandomenico, Chem. Rev., 1999, 99, 2451-2466.

10 Y. P. Ho, S. C. F. Au-Yeung and K. K. W. To, Med. Res. Rev., 2003, 23, 633-655.

11 L. Ronconi and P. J. Sadler, Coord. Chem. Rev., 2007, 251, 1633-1648.

12 K. D. Mjos and C. Orvig, Chem. Rev., 2014, 114, 4540-4563. 13 A. Taylor and N. Carmichael, Cancer Studies, 1953, 2, 36-79. 14 M. J. Cleare and P. C. Hydes, Met. Ions Biol. Syst., 1980, 11, 162.

15 G. Mestroni, E. Alessio, A. Sessanta o Santi, S. Geremia, A. Bergamo, G. Sava, A. Boccarelli, A. Schettino and M. Coluccia, Inorg. Chim. Acta, 1998, 273, 62-71.

16 I. Haiduc and C. Silvestru, "Cobalt, Rhodium and Iridium" in Organometallics in Cancer Chemotherapy, CRC Press, Boca Raton, Florida, 1990, pp. 169-207.

17 N. Katsaros and A. Anagnostopoulou, Crit. Rev. Oncol. Hematol., 2002, 42, 297-308.

18 (a) G. Gupta, E. Denoyelle-Di-Muro, J.-P. Mbakidi, S. LeroyLhez, V. Sol and B. Therrien, J. Organomet. Chem., 2015, 787, 44-50; (b) H. Pruchnik, M. Latocha, A. Zielińska and F. P. Pruchnik, J. Organomet. Chem., 2016, 822, 74-79; (c) M. Kalidasan, S. Forbes, Y. Mozharivskyj, M. Ahmadi, Z. Ahmadihosseini, R. M. Phillips and M. R. Kollipara, Inorg. Chim. Acta, 2014, 421, 349-358; (d) O. Dömötör, S. Aicher, M. Schmidlehner, M. S. Novak, A. Roller, M. A. Jakupec, W. Kandioller, C. G. Hartinger, B. K. Keppler and É. A. Enyedy, J. Inorg. Biochem., 2014, 134, 57-65; (e) H.-R. Zhang, Y.-C. Liu, Z.-F. Chen, T. Meng, B.-Q. Zou, Y.-N. Liu and H. Liang, New J. Chem., 2016, 40, 6005-6014.

19 S. Schäfer, I. Ott, R. Gust and W. S. Sheldrick, Eur. J. Inorg. Chem., 2007, 19, 3034-3046.

20 M. A. Nazif, R. Rubbiani, H. Alborzinia, I. Kitanovic, S. Wölfl, I. Ott and W. S. Sheldrick, Dalton Trans., 2012, 41, 55875598.

21 Y. Geldmacher, K. Splith, I. Kitanovic, H. Alborzinia, S. Can, R. Rubbiani, M. A. Nazif, P. Wefelmeier, A. Prokop, I. Ott, S. Wölfl, I. Neundorf and W. S. Sheldrick, J. Biol. Inorg. Chem., 2012, 17, 631-646.

22 Y. Geldmacher, M. Oleszak and W. S. Sheldrick, Inorg. Chim. Acta, 2012, 393, 84-102.

23 G. H. Y. Lin, J. D. Leggett and R. M. Wing, Acta Crystallogr., Sect. B: Struct. Crystallogr. Cryst. Chem., 1973, 29, 1023-1030.
24 D. Cremer and J. A. Pople, J. Am. Chem. Soc., 1975, 97, 13541358.

25 U. Rychlewska, M. I. Djuran, B. Warżajtis, D. D. Radanović, M. M. Vasojević and D. J. Radanović, Polyhedron, 2003, 22, 3265-3276.

26 A. E. Martell and R. M. Smith, Critical Stability Constants, Plenum Press, New York, 1974, vol. 1-4.

27 P. Gans, A. Sabatini and A. Vacca, Talanta, 1996, 43, 17391753.

28 P. Djurdjevic, R. Jelic, L. Joksovic, I. Lazarevic and M. JelikicStankov, Acta Chim. Slov., 2010, 57, 386-397.

29 P. Gans, A. Sabatini and A. Vacca, Ann. Chim., 1999, 89, 45-49. 30 É. A. Enyedy, O. Dömötör, C. M. Hackl, A. Roller, M. S. Novak, M. A. Jakupec, B. K. Keppler and W. Kandioller, J. Coord. Chem., 2015, 68(9), 1583-1601.

31 S. I. Bezzubov, V. D. Dolzhenko and Y. M. Kiselev, Zh. Anal. Khim., 2012, 67(2), 176-179.

32 M. J. Frisch, G. W. Trucks, H. B. Schlegel, G. E. Scuseria, M. A. Robb, J. R. Cheeseman, G. Scalmani, V. Barone, B. Mennucci, G. A. Petersson, H. Nakatsuji, M. Caricato, X. Li, H. P. Hratchian, A. F. Izmaylov, J. Bloino, G. Zheng, J. L. Sonnenberg, M. Hada, M. Ehara, K. Toyota, R. Fukuda, J. Hasegawa, M. Ishida, T. Nakajima, Y. Honda, O. Kitao, H. Nakai, T. Vreven, J. A. Montgomery Jr, J. E. Peralta, F. Ogliaro, M. Bearmark, J. J. Heyd, E. Brothers, K. N. Kudin, V. N. Staroverov, R. Kobayashi, J. Normand, K. Raghavachari, A. Rendell, J. C. Burant, S. S. Iyengar, J. Tomasi, M. Cossi, N. Rega, J. M. Millam, M. Klene, J. E. Knox, J. B. Cross, V. Bakken, C. Adamo, J. Jaramillo, R. Gomperts, R. E. Stratmann, O. Yazyev, A. J. Austin, R. Cammi, C. Pomelli, J. W. Ochterski, R. L. Martin, K. Morokuma, V. G. Zakrzewski, G. A. Voth, P. Salvador, J. J. Dannenberg, S. Dapprich, A. D. Daniels, O. Farkas, J. B. Foresman, J. V. Ortiz, J. Cioslowski and D. J. Fox, Gaussian09, revision A.1, Gaussian, Inc., Wallingford, CT, 2009.

33 MOMEC97, a molecular mechanics program for coordination compounds adapted to HyperChem: http:// www.uni-heidelberg.de/comba-group; molecular modeling. 34 (a) P. V. Bernhardt and P. Comba, Inorg. Chem., 1992, 31, 2638-2644; (b) P. Comba, T. W. Hambley and M. Ströhle, Helv. Chim. Acta, 1995, 78, 2042-2047; (c) J. E. Bol, C. Buning, P. Comba, J. Reedijk and M. Ströhle, J. Comput. Chem., 1998, 19, 512-523.

35 (a) S. Kumar, Cell Death Differ., 2007, 14, 32-43; (b) M. Vogler, D. Dinsdale, M. J. S. Dyer and G. M. Cohen, Cell Death Differ., 2009, 16, 360-367.

36 (a) C. Adrain and S. J. Martin, Sci. Signaling, 2009, 2, pe62; (b) S. E. Logue and S. J. Martin, Biochem. Soc. Trans., 2008, 36, 1-9. 37 R. Kim, M. Emi, K. Tanabe, Y. Uchida and K. Arihiro, Eur. J. Surg. Oncol., 2006, 32, 269-277.

38 G. Koopman, C. P. Reutelingsperger, G. A. Kuijten, R. M. Keehnen, S. T. Pals and M. H. van Oers, Blood, 1994, 84, 1415-1420.

39 H. Lecoeur, M. C. Prévost and M. L. Gougeon, Cytometry, 2001, 44, 65-72. 
40 D. Baskic, S. Popovic, P. Ristic and N. N. Arsenijevic, Cell Biol. Int., 2006, 30, 924-932.

41 L. Galluzzi, I. Vitale, J. M. Abrams, E. S. Alnemri, E. H. Baehrecke, M. V. Blagosklonny, T. M. Dawson, V. L. Dawson, W. S. El-Deiry, S. Fulda, E. Gottlieb, D. R. Green, M. O. Hengartner, O. Kepp, R. A. Knight, S. Kumar, S. A. Lipton, X. Lu, F. Madeo, W. Malorni, P. Mehlen, G. Nuñez, M. E. Peter, M. Piacentini, D. C. Rubinsztein, Y. Shi, H.-U. Simon, P. Vandenabeele, E. White, J. Yuan, B. Zhivotovsky, G. Melino and G. Kroemer, Cell Death Differ., 2012, 19, 107-120.

42 S. Fulda and K. M. Debatin, Oncogene, 2006, 25, 4798-4811. 43 CrysAlisPro, Agilent Technologies UK Ltd, Oxford, UK, 20112014.

44 W. R. Busing and H. A. Levy, Acta Crystallogr., 1957, 10, 180-182. 45 (a) G. M. Sheldrick, SHELXT, University of Göttingen and Bruker AXS GmbH, Karlsruhe, Germany, 2012-2014; (b) M. Ruf and B. C. Noll, Application Note SC-XRD 503, Bruker AXS GmbH Karlsruhe, Germany, 2014; (c) G. M. Sheldrick, Acta Crystallogr., Sect. A: Found. Adv., 2015, 71, 3-8.
46 (a) P. T Beurskens, G. Beurskens, R. de Gelder, J. M. M.Smits, S. Garcia-Granda and R. O. Gould, DIRDIF-2008, Radboud University Nijmegen, The Netherlands, 2008; (b) P. T. Beurskens, in Crystallographic Computing 3, ed. G. M. Sheldrick, C. Krüger and R. Goddard, Clarendon Press, Oxford, UK, 1985, pp. 216-266.

47 (a) G. M. Sheldrick, SHELXL-20xx, University of Göttingen and Bruker AXS GmbH Karlsruhe, Germany, 2012-2014; (b) G. M. Sheldrick, Acta Crystallogr., Sect. A: Found. Crystallogr., 2008, 64, 112-122; (c) G. M. Sheldrick, Acta Crystallogr., Sect. C: Struct. Chem., 2015, 71, 3-8.

48 L. Alderighi, P. Gans, A. Lenco, D. Peters, A. Sabatini and A. Vacca, Coord. Chem. Rev., 1999, 184, 311-318.

49 F. Weigend and R. Ahlrichs, Phys. Chem. Chem. Phys., 2005, 7, 3297-3305.

50 HyperChem $^{\mathrm{TM}}$, Hypercube, Inc., 1115 NW 4th Street, Gainesville, Florida 32601, USA.

51 T. Mosmann, J. Immunol. Methods, 1983, 65, 55-63.

52 T. C. Chou and P. Talalay, Adv. Enzyme Regul., 1984, 22, 2755.

53 M. M. Bradford, Anal. Biochem., 1976, 72, 248-254. 